\title{
Current status of viral diseases of potato and their ecofriendly management -A critical review
}

\author{
Awasthi LP1* and Verma $\mathrm{HN}^{2}$ \\ ${ }^{1}$ Amity Center for Research and Innovation, Amity University Uttar Pradesh, Varanasi, U.P, India \\ Jaipur National University, Jaipur, Rajasthan, India
}

\section{Introduction}

Potato (Solanum tuberosum L.) belongs to family solanaceae of dicotyledons and well known as the king of vegetables. Potatoes are acclaimed around the globe as the power house of energy. It is known for sustaining millions of lives by providing food and nutrition during the war and hunger. This crop has special significance to the developing countries as it has high production potential per unit area and time with high nutritional value. At global level about 328.87 million tons of potato is produced from 19.13 million hectare land with an average productivity of about 17.19 tonnes/ha. In India, potato is cultivated from about 1.4-million-hectare land with production of about 25 million tones and 17.86 tonnes/ha productivity [1]. It is an alien crop to India, produces about $23.6 \mathrm{mt}$ of potato from 1.31 million hectares with average yield of $17.9 \mathrm{t} / \mathrm{ha}$ [2]. Due to its diversified uses in developed countries as food, feed and raw material for producing starch and alcohol, potato is generally thought to be a crop providing staple food in several countries of the world. The high production potential per unit area, high nutritional value and great taste make potato as one of the most important food crop in the world.

\section{Historical}

Thousands of years before the Incas developed an empire (1532) in the region that now includes Peru, Chile and Bolivia. All the cultivated potato come originally from a single species grown in Southern Peru. There are about two hundred species of wild potatoes still growing in the world. But for most of the world, the potato is represented by a single species i.e. Solanum tuberosum. Around 1580, potato was introduced to Ireland. The amount of potatoes raised in Ireland increased rapidly throughout the eighteenth country. Between 1780 and 1840, the Irish population doubled from four to eight million. This increase put more pressure on the land and caused rends to rise, leaving as many as a third of the population entirely depend on smaller plots and the potatoes they could grow on them. High-yielding potatoes called the Lumper, an import from Scotland where it had been used only for feeding stock. In France, a series of famines and failures of the wheat crop in the eighteen century eventually convinced the government that the potato would be a good hedge against starvation. Frederick, King of Prussia and prisoner during the seven-year war in Prussia, did not limit himself to suggesting that his peasants grow potatoes to prevent the starvation of his army. By the end of nineteenth century Europe led the world in both potato production and consumption, including consumption as Vodka distilled from the tubers. In North America, country where potato growing was adopted voluntarily by the population, white potato was introduced in the eighteenth century. By the mid-nineteenth century, with the introduction of long-day varieties, it was the most popular vegetable grown in the US. The impact of American potatoes into Europe during and after WW II is sometimes blamed for its spread into Germany and Eastern Europe. Throughout most of the twentieth century; Northern Europe led the world in potato production, with Russia in first place. In the last couple of decades, however, potato cultivation has begun on a large scale in Asia. Now, the number one producer of potatoes in the world is China, which grew twice as much of this crop as Russia in 2007. In Bangladesh, it is being promoted as a winter crop during the dry season. Increased cultivation is also being promoted in the Sub-Saharan and highland region of Africa. India is the $3^{\text {rd }}$ largest potato producer in the world after China and Russia [3].

\section{In Indian cotext}

In India potato was introduced from Europe in early $17^{\text {th }}$ century. Since, 1830 it is being grown as a commercial crop [4]. Potato is a world food crop and can be compared only with rice, wheat and maize for its contribution towards securing the food and nutrition and avoiding the poverty and hunger, especially in developing world where food is perpetually on demand to feed the increasing population living with inherent social and political conflicts. The first mention of the potato in literature was in 1553 and first published illustration appeared in 1633. It was introduced into Europe soon after 1580 by the Spaniards and by the end of $17^{\text {th }}$ century; it was spread all over Europe. Prior to 1700 , it was grown as a garden vegetable in parts of western India, while it reached southern India only in the 1880s. The British promoted potato cultivation in the hills and it spread to plains by 1900 . Potato has been identified as staple food and richest source of carbohydrate. It is used as vegetable alone and mixed with other vegetables. It is used in preparation of brief products (chips and frozen French fries), dehydrated products (dices, waries, flakes granules, starch, gravy thickener, potato custard powder etc.) and canned potato [5].

Potato produces $3 \mathrm{~kg}$ of edible protein/ha/day as compared to 2.5 $\mathrm{kg}$ and $1.0 \mathrm{~kg}$ in wheat and rice, respectively. Potato also produces more carbohydrate, fiber and vitamins per unit area and per unit time than other major food crops [6]. Conventionally it is thought that potato is a good source of energy but has little nutritive value. In fact, the potato is a balanced food containing less energy but substantial amounts of high quality protein, essential vitamins, minerals and trace elements. Due to higher protein-to-calorie ratio potato is more nutritive food than

Correspondence to: Awasthi LP, Amity Center for Research and Innovation, (Amity University Uttar Pradesh), Varanasi-221007, U.P, India, Tel: 919415718904; E-mail: lpawasthi14@gmail.com

Received: July 16, 2017; Accepted: August 14, 2017; Published: August 16, 2017 
other root crops and most of the cereals. If one satisfies one's entire protein requirement with potatoes, one could still be short of calories. This illustrates the error of considering the potato as a primary source of energy.

Poverty and population size are significant and persistent problems in India. A major consequence is hunger. These problems, besides having close relationship with food insecurity, are also closely related to poor health and malnutrition. Food security in developing countries is, therefore, an important national objective. Potato produces more nutritious food per unit land and time than many other crops. Potato yield about $90-100$ kilocalories per $100 \mathrm{~g}$ and contain 80 per cent water of its fresh weight [7].

Nearly 80 per cent of potatoes are grown in vast Indo-Gangetic plains of north India during short winter days from October to March. About 8 per cent area under potato cultivation lies in the hills where the crop is grown during long summer days of April to October. Plateau regions of South-Eastern, Central and Peninsular India, constitute about 6 per cent area where potatoes are grown as a rainfed kharif crop during rainy season (July to October) or as irrigated rabi crop during winter (November to March). In a small area of about 4,000 ha covering mainly the Nilgiri and Palani hills of Tamil Nadu, the crop is grown round the year both as irrigated and rainfed crop. The states of Uttar Pradesh, West Bengal and Bihar account for nearly 73 per cent of the area under the crop in India and 80 per cent of the total production [8]. In Uttar Pradesh, potato is cultivated in 0.42 million ha with production of $11.09 \mathrm{~m}$ tonnes during 2007-08 [9].

\section{Disease Scenario}

Despite the introduction of high yielding varieties and improved cultural practices, the per unit area production of potato is low due to different biotic and abiotic stresses including viruses. Viral diseases play a significant role in reducing the yield potentiality of the crop. These diseases cause heavy losses to the crop and prove a limiting factor in its successful cultivation. In India, occurrence of potato viruses had been noticed more than 60 year ago in Punjab [10]. Among the viral diseases, mosaic, stunting, necrosis and leaf roll are most important and caused by several viruses i.e. Potato Virus X (PVX), Potato Virus Y (PVY), Potato Virus A (PVA), Potato Virus M (PVM), Potato Virus $S$ (PVS), Potato aucuba virus, mop-top virus, potato leaf roll virus (PLRV) and potato apical leaf roll virus (APLRV) in all potato growing zones of India [11]. Insects (aphid, beetle, leaf hopper and whitefly), fungi and seeds serve as source and vector of virus transmission [12].

The severe strains of potato virus $\mathrm{Y}$ and leaf roll may cause 60-75 per cent loss in tuber yield while the mild ones like potato virus $X, S$, $\mathrm{A}$ and $\mathrm{M}$ may depress the yields by $10-30$ per cent $[13,14]$. Continuous use of old infected seed stocks upto 3-4 years bringing down their yielding ability to almost 50 per cent [Table 1] $[13,14,15]$.

Efforts have been made to collect relevant literature on different aspects of major viral diseases of potato and presented here in under:

\section{Epidemiological studies}

Peters and Jones [16] reported that moderate temperatures and dry weather favours the spread of PLRV by aphid (Myzus persicae). Hiruki [17] revealed that symptoms of PVM transmitted by aphids are masked at temperature approximately $24^{\circ} \mathrm{C}$ and above. Symptoms in most plants are enhanced by low temperatures of $16-20^{\circ} \mathrm{C}$ and are mild or may be masked at temperature above $28^{\circ} \mathrm{C}$ [18]. The concentration of PLRV in leaf extracts differed only slightly when potato plants were kept
Table 1. Common viral diseases of potato.

\begin{tabular}{|c|c|c|}
\hline S.No & Disease symptoms & Causal virus \\
\hline 1. & Potato leaf roll & Potato leaf roll virus \\
\hline 2. & Mild mosaic & Potato virus X \\
\hline 3. & Yellow flecking & Potato acuba mosaic virus \\
\hline 4. & Rugore mosaic & Potato virus Y \\
\hline 5. & Mild mosaic & Potato virus A \\
\hline 6. & Symptomless or mild rugosity & Potato virus S \\
\hline 7. & Symptomless or para crinkling of leaves & Potato virus M \\
\hline 8. & Chlorosis and mild mosaic & Andean Potato Latent virus \\
\hline 9. & Yellow mottling & Alfalfa mosaic virus \\
\hline 10. & Bright yellow blotches and rings & Potato Mop-top virus \\
\hline
\end{tabular}

at $15,20,25$ or $30^{\circ} \mathrm{C}$ for 1 or 2 weeks, but the virus content of aphids kept on leaves at the different temperatures decreased with increase in temperature. PLRV could be transmitted readily to P. floridana at all temperatures and after a longer latent period, at $15^{\circ} \mathrm{C}$ than $30^{\circ} \mathrm{C}$. The population of aphids was decreased faster at 25 and $30^{\circ} \mathrm{C}$ that 15 and $20^{\circ} \mathrm{C}[19]$.

Incidence of aphid species i.e., M. persicae and A. gossypii was initiated first during third week of December in Kufri Chandramukhi while in Kufri Jyoti and Kufri Jawahar the pest appeared first during end of December. The incidence of aphids on Atlantic was found quite later during first week of January and on Kufri Chipsona-1 and Kufri Chisona-2 during second weed of January. In K. Chandramukhi the aphids crossed the critical level (20 aphids/100 compound leaves) earlier than other germplasm, i.e., during first week of January whereas in $\mathrm{K}$. Jyoti and $\mathrm{K}$. Jawahar the pest attained the threshold limit during second week of January. On the other hand, the pest reached the critical level between fourth week of January to first week of February in all the three processing varieties viz. K. Chipsona-1, K. Chipsona-2 and Atlantic germplasms of potato. During this period, the maximum and minimum temperature ranged from $27.2^{\circ} \mathrm{C}$ to $9.5^{\circ} \mathrm{C}$ and minimum and maximum relative humidity varied from $46.3 \%$ to $99.7 \%$ with 2.9 $\mathrm{mm}$ average rainfall [20].

\section{Potato virus X}

\section{Geographical distribution}

It is the type member of the genus potyvirus and distributed worldwide. The virus is also known as potato latent virus, Potato mottle virus, potato interveinal mosaic virus, tobacco ringspot virus, up-to-date streak virus, potato virus $B$, potato virus $D$, healthy potato virus and potato mild mosaic virus [21,22]. English-speaking people refer it as potato latent mosaic or potato mottle. French call it rivose masquell de lapomme de terre or mosaique legere. Spanish names for the disease are mosaic leve and mosaic latente de la papa. German refer it as Krausel mosaic or leichtes mosaic der Kartoffel.

\section{Symptomatology}

Infected plants with only mild symptoms in the upper leaves may show typical symptoms in the older leaves shaded by the top foliage. Such older leaves do not turn uniformly yellow but have a greenish banding of veins on a yellow background [21]. Blotchy type of mottling, waviness and undulating margins etc., in potato plants infected with PVX and PVA was noted by Pushkarnath in year 1964 [23]. Under cool, cloudy condition potato cultivars may develop as mottle, interveinal mosaic, mild mosaic and supermild mosaic [22,24]. Cariboo and York are two Canadian cultivars which exhibited a corky necrosis [25-27].

In many potato varieties PVX evokes an interveinal mosaic but in some plants rugosity of the leaves or even crinkling has been reported 
by Brien and Rich [28]. Sharma, et al. [29] and Rich [30] reported mild imperceptible mottling of potato leaves (light green patches) which leads the chlorosis and stunning of the potato plants infected with PVX. Potato virus X cause less perceptible mosaic which can be seen in shade or when a white card is held behind the leaf [31,32]. Mild mosaic and stunting PVX symptoms were observed by Jung, et al. [33] in Koria. PVX (potex virus) usually causes faint mottle or interveinal mosaic in very young plants depending upon the varieties. The symptoms are more clear at low temperature. PVX in combination with PVY produces rugose mosaic while crinkle mosaic is the result of PVA combination. In some cultivars tuber necrosis is also reported Kumar, et al., [34-37]. Uniyal reported the mild mosaic symptom in potato crop by Potato virus X [11]. The mild mosaic is the general symptom clearly visible on young plants at the beginning of infection. As the season progresses due to increasing temperature, the mosaic symptom becomes less apparent [38]. Agrios [39] reported the mosaic and stunting symptom of Potexvirus (PVX) in potato plant. Major symptom of PVX are mosaic and dwarfing on potato plants but in potato cultivar Craigs Defiance to necrosis was observed [40-43].

\section{Transmission}

Smith reported that PVX can be easily transmitted by sap inoculation, stem and tuber core grafting but chewing insects (eg. grasshoppers) can also transmit it in the same way as clothing and fur [21]. Potato virus $\mathrm{X}$ is easily transmitted by sap inoculation, stem and tuber-core grafting, grasshoppers and other chewing insects $[43,44]$. Potato virus $\mathrm{X}$ can be transmitted through cutting, grafting and sap inoculation from infected to fresh potato plants [28]. Munro told that PVX can be transmitted through grasshoppers, zoospores of Synchytrium endobioticum and contact of plant parts in the field [45]. Khurana and Singh experimentally proved that PVX can be transmitted as a contamination on the surface of wart pathogen (Synchytrium endobioticum) and by beetles [46]. Kumar, et al. [34] reported that PVX is readily transmitted by mechanical inoculation, Zoospores of S. endobioticum and Cuscuta compestris. Damadi, et al. demonstrated that the sap inoculation of PVX by potato leaves and tubers produced local lesion on Gomphrena globosa, Chenopodium spp. and mosaic on Nicotiana spp. and Datura stramonium [47]. They further reported that the sap from N. glutinosa was in effective after dilution to $10^{-6}, 10$ minutes at $70^{\circ} \mathrm{C}$ and 10 weeks at room temperature.

Silva, et al. reported the mechanical transmission of PVX on several host plants and also demonstrated the distinct symptom on $N$. glutinosa and Physalis floridana by P21 and VEL isolates of PVX [48]. Gullino [33] transmitted PVX from infected leaves to healthy plants with sap inoculation without using carborundum. The PVX virus can be transmitted through mechanical inoculation. Agrios, Singh $[13,39]$ reported the contact transmission of PVX while, El-Muadhidi and Habib [49] reported the transmission of PVX by Wright ground cherry (Physalis wrightii) seeds upto $0.7 \%$. They also demonstrated the incidence of PVX in same weed 2.3 to $3.0 \%$ in Arab. Bawden reported the mechanical and grafting inoculation of potato virus X [41].

\section{Host range}

The natural host range of PVX appears to be limited almost entirely to potato and tomato [24]. Experimental hosts include about 15 angiosperm families. Plants which can become infected with PVX include Nicotiana tabacum, N. glutinosa, Datura stramonium, Solanum dulcamara, S. nigrum, Hyoscyamus niger, Cyphomandra betacea, Petunia sp., Crimson clover (Trifolium incarnatum) and other legumes. Symptoms vary with the strain of PVX and the species or cultivar of the host [22,24,50,52]. Harison [22] reported that PVX cause necrotic local lesions on Gomphrena globosa and chlorotic, necrotic or ring spot local lesions on Chenopodium amaranticolar.

Munro told that PVX cause systemic infection which leads the mottles/ringspot in N. tabacum, severe mottle and leaf necrosis in D. stramonium and local lesion in Gomphrena globosa plants [18,41]. PVX cause local lesion in Gomphrena globosa, vein clearing, mottling and ringspot in tobacco plants and necrotic lesions in Capsicum annum [53]. Dijk, et al. [54] and Dijk and Cuperus [55] used plants of Nicotiana genus as test against PVX. N. benthimiana, N. occidentalis, N. Hesperis, Chenopodium amaranticolar and C. quinon plants were used for the detection of PVX [56,57]. Nicotiana tabacum, N. rustica and tomato are the propagation hosts of PVX [58,59]. Watts, et al. reported three Canadian isolates of Potato X Potevirus (PXV) that produced distinctly different symptoms in tobacco (Nicotiana tabacum cv. Samsun) by the analysis of their coat protein using SDS-PAGE [60]. He also told that Canadian isolates that produced severe or intermediate symptoms were identical to symptoms of PVX isolates from Argentina, China, Netherlands and UK. Baranova, et al. use Datura stramonium as host plant for the study of the template dependency and specificity of RNAdependent RNR-polymerase of potato virus X (PVX) and revealed that RNA-dependent RNA-polymerase of PVX can initiate the synthesis of new RNA sequences only on the homologous RNA [61].

Kumar, et al. observed the local lesion in Capsicum annum L., Chenopodium amaranticolar, C. quinoa, Gomphrena globosa, Systemic infection in D. straminium, Lycopersicon esculentum Mill., N. clevelandii Gray, N. debneyiii, N. glutinosa, and Physalis floridana but both i.e., systemic and local infection in D. metel, N. tabacum and Solanum demissum ' $\mathrm{A}^{6}$ ' [37]. Escobar, et al. used Nicotiana benthamiana for over-expression of Arabidopsis thaliana ascorbate peroxidase 3 (APX 3) by using a viral vector based on Potato virus X (PVX) and showed that plant infected with a PVX : APX 3 hybrid had a similar progression of viral particles compared to control plants infected with a PVX : GFP hybrid, indicating that infection was not affected by the over-expression of heterologous APX 3. Biswas, et al. collected thirtysix weeds in a potato field in West Bengal, India and tested the presence of Potato virus X by serologically and through mechanical transmission on potato and indicator plants and concluded that Melilotus alba, Nicotiana plumba ginifolia and Solanum torvum were hosts of PVX. Gonzalez-Jara, et al. made a comparative analysis of the synergistic interaction between PVX and either PVY or TEV potyvirus in Nicotiana benthamiana and N. tabacum plants and concluded that PVX and potyviruses contain suppressors of a plant antiviral defence system mediated by gene silencing, differences observed in the response of these two related hosts of PVX/potyvirus interactions might reflect the effect of these viruses on host specific antiviral defences [62]. Howard, et al. conducted many experiments to compare the plasmodesmal transport activities of Potato virus X (PVX) TGBp1 and coat protein $(\mathrm{CP})$ in several plant species through microinjection and reported that GFP/TGBp1 moved between adjacent cells in N. tabacum, N. clevelandii, $N$. benthamiana and Lycopersicon esculentum, whereas GFP/CP moved only in N. benthamiana leaves [63].

Balogun, et al. used the primary leaves of seedlings of tomato (Lycopersicon esculentum Mill.) cultivars Fukuju No.2. for the inoculation of $\mathrm{O}$ strain of potato virus $\mathrm{X}(\mathrm{PVX})$ and Tomato mosaic virus (ToMV) and reported the varying degrees of disease manifestation between 5 and 12 days to post inoculation [64]. Sapotky, et al. used thorn-apple plants (Datura stramonium L.) to categorized the isolates of potato virus $\mathrm{X}$ in terms of increase in antigen accumulation and 
reported that plants infected with the strong isolate had higher total content of PR-proteins than healthy plants and plants infected with weak or medium isolates [65]. Kagiwada, et al. revealed that a potato virus X strain, PVX-OS causes a necrotic mosaic in Nicotiana benthamiana and ring spot mosaic in N. tabacum cv. Samsun NN [66]. He also told that another potato virus strain i.e. PVX-BS cause a mild mosaic in N. benthamiana and systemic asymptomatic infection in $N$. tabacum cv. Samsun NN.

Komatsu, et al. reported that five Japanese PVX strains (PVXBS, -BH, -OG, -TO, -OS) differ in their pathogenicity in wild potato (Solanum demissum) and tobacco (N. tabacum cv. Samsun NN) [67]. He also reported that genomic sequences of these five PVX strains were highly homologus (i.e. the nucrleotide sequence identity ranged from 95.4 to $98.5 \%)$. Durate, et al. selected the leaves of Datura stramonium to study the effect of potato virus X (PVX) on the contents of total phenols and alkaloids and reported a significant decrease in the contents of phenols and alkaloids in leaves. Li ,et al. reported that approximately $70 \%$ of surveyed Orychophragmus violaceus plants in Beijing, China where infected with PVX by using ACP-ELISA and PCR analysis [68]. Petrzik screened two dock (Hybrid dock of Uteush) farming localities situated in south-west and north-east part of the Czech Republic for the presence of potyvirus, poteviruses and carlaviruses and reported that north- east part of the country showed high incidence of potato virus $\mathrm{X}$ but north east part of the country did not showed any dock plants infected with PVX [69]. Reunov et al. (2009) studied the influence of fucoidan from the brown alga Fucus evanescens on the development of infection induced by potato virus $\mathrm{X}(\mathrm{PVX})$ in Datura stramonium leaves and concluded that $24 \mathrm{~h}$ after treatment of the leaves with fucoidan and following inoculation with PVX, the infectivity and amount of the virus in the leaves as well as the accumulation of viral particles in infected cells during early infection period were substantially less than those in the untreated control [70]

\section{Bio-physical properties of PVX}

Thermal inactivation point of $\mathrm{PVX}$ is $68-76^{\circ} \mathrm{C}$, dilution end point is $10^{-5}-10^{-6}$ and infectivity of virus depend on the strain and vary from several weeks to a year [21,22,24,30,38,43,45]. According to Agrios [39] potexvirus (PVX) are flamentous particles having ssRNA genome. Mossahebi, et al. reported that sap from PVX infected Nicotiana glutinosa was ineffective after dilution to $10^{-6}$, after 10 minutes at $70^{\circ} \mathrm{C}$ and after 10 weeks at room temperature [71].

Singh reported that thermal inactivation point of the virus lies between $68^{\circ} \mathrm{C}$ and $76^{\circ} \mathrm{C}$, depending on the strain. The dilution end point is $1: 10000$ to $1: 100000$. Infectivity is retained for several weeks at $20^{\circ} \mathrm{C}$ and for more than a year in the presence of glycerol [72].

\section{Serological and nucleic acid based studies}

Wright, et al. prefer the latex agglutination test for the identification of PVX [73]. Darda used potato tubers infected with potato virus X potevirus (PVX) to compare the sensitivity of amplified ELISA and DAS-ELISA and reported that ELISA was the most sensitive than DASELISA [74]. Ghaffer, et al. used ELISA, western blot analysis and electron microscopy to see the effect of temperature on the multiplication of potato X potevirus (PVX) in tobacco (cv. Xanthi) plants and concluded that PVX-inoculated plants grown at $32^{\circ} \mathrm{C}$ showed no virus but an appreciable concentration of PVX was found in plants grown at $22^{\circ} \mathrm{C}$ [75]. Soliman, et al. made a rapid and sensitive assay for the specific detection of plant viruses using reverse transcription-polymers chain reaction (RT-PCR) [76]. They also used probe hybridization (RT-PCR-
ELISA) for detection and characterization of an isolate of potato virus $\mathrm{X}$ from infected potato tissues collected in Egypt. Jung, et al. showed mild mosaic and stunting symptoms of PVX (PVX-KO) and detected by gel-immuno-diffusion tests and ELISA [33]. A rapid and sensitive assay for the specific detection of plant viruses using RT-PCR and ELISA was applied successfully to characterized an isolate of PVX from infected potato tissues collected in Egypt and in India [77].

Slack reported that enzyme linked immunosorbant assay (ELISA) and nucleic acid probes are suitable for the detection of all PVX strains [78]. Balogun, et al. reported that the concentration of PVX in upper 5 to 7 leaves of doubly infected plants was three to six-fold than those of singly infected plants as determined by DAS-ELISA in tomato $\mathrm{cv}$ [79]. Fukujo No. 2. Zhang et al. [80] showed that the infection of PVX was systemic in potato cv. Zhongdianhong by using enzyme-linked immunosorbent assay (ELISA) and immunosorbent electron microscopy (ISEM). Qu-Jing, et al. [81] obtained an isolate of potato virus $\mathrm{X}$ from potato plants in Shandong Province, China and amplified the coat protein (CP) of viral RNA extracted by using reverse transcription-polymerase chain reaction (RT-PCR) and cloned into plasmid $\mathrm{pUC}_{19}$ and concluded that coat protein shares $80.1-99.7 \%$ and $89.8-100 \%$ homology with the reported isolates at the sequence levels of nucleotide and reduced amino acids, respectively. Wu and Zhou studied PVX spread by using ACP-ELISA based on 2 MAbs and resulted the widespread of PVX in field potatoes [82]. Cerovska, et al. studied the effect of storage conditions on the serological activity of L2ACPE7 by ELISA using IgG anti PVX and reported that purified L2ACPE7 was most stable as lyophilized material stored at $-20^{\circ} \mathrm{C}[83]$.

\section{Morphology of virus particles}

Potato virus X particles are thread like in structure with size 515 x $13 \mathrm{~nm}$ [21]. Beemster and Rozendaal in year 1972 [84] reported the thread like (515 x $13 \mathrm{~nm})$ structure of PVX. Bercks [58], Koening and Lesemann [85] and Hutting and Matt [59] told that PVX particles are flexuous, $515 \times 13 \mathrm{~nm}$, helically constructed with apitch of $3.4 \mathrm{~nm}$ and particles contain $6 \%$ ss RNA (by weight). PVX particles are flexuous, filaments, $515 \times 13 \mathrm{~nm}$, with helical sub-structure, single standard ribonucleic acid with molecular weight of $2.1 \times 10^{6}[30,45]$ and Slack reported that PVX is the type member of the genus Potexvirus and particles are flexuous rods $(515 \times 13 \mathrm{~nm})$ with a helical substructure having a pitch of $3.4 \mathrm{~nm}$ [78]. The particles of the virus are flexuous rods, measuring about $515 \times 13 \mathrm{~nm}$ in size with sedimentation coefficient of $117 \mathrm{~S}[38,39]$. Singh reported that virus particles are flexuous filaments measuring 450-540 × $13 \mathrm{~nm}$ [42]. Atabekov, et al. summarized the structural characteristics of PVX as flexuous and filamentous particle [86].

\section{Varietal screening}

Agur [87] reported the incidence of PVX in Tallinn (Estonia) and evaluated the potato cultivars against the three isolates of potato virus $\mathrm{X}$ by seeing the degree of susceptibility/resistance, virus biosynthesis and symptoms of infection in inoculated plants (first year) and from the tubers germination (second year) and resulted that Timate, Sante and Sarme were immune, while varance Kollane was highly (100\%) susceptible to all three isolates. But in Ants, Berber, Lazunak, Prigozle and Procusa the degree of susceptibility/resistance, virus biosynthesis and symptom depends not only on variety but also on virus isolate. Khan and Naveed screened twenty-one potato cultivars for resistance to potato virus $\mathrm{X}$ under green house and field experiments in Pakistan and concluded that eleven cultivars were moderately resistance to potato virus X (PVX) $[88,89]$. The correlation between environmental factors and the severity of potato virus $\mathrm{X}$ in potato cultivars were 
studied in Pakistan by Naveed, et al. [90] and the study revealed that 18 cultivars were negatively correlated with maximum $\left(15-31^{\circ} \mathrm{C}\right)$ and minimum $\left(5-13^{\circ} \mathrm{C}\right)$ temperature respectively but positively correlated with relative humidity (72-88\%). Kumar, et al. reported serotype PVX occurs worldwide including India, where as $\mathrm{PVX}^{3}$ has restructed occurrence, $\mathrm{PVX}^{\mathrm{CP}}$ strain is present in the south-central Andes of Peru, $\mathrm{PVX}^{\mathrm{HB}}$ strain in the Bolivian plateau around lake Titicaca and recently an MS strain has been described in Solanum acaule and Serrana INTA [91,92]. Uniyal [11] reported the incidence of PVX in cv. Kufri Jyoti, K. Megha, K. Kanchan and K. Giriraj in North-East India. Singh [93] reported the occurance of $\mathrm{PVX}_{\mathrm{HB}}$ strain in South America, Europe and India. Mossahebi, et al. [71] collected the potato tuber in Damavand area and compared with tubers of Ardadil area (Iran) and resulted that the disease incidence in Damavand ranged from 1.1-20.9\% and was lower than the disease incidence in Ardabil area. According to Bawden $[40,41]$ potato virus $\mathrm{X}$ is widely distributed virus in potato in districts of England and reduce the tuber yield.

Lamber, et al. studied the spread of Potato virus X in seed potato in Tasmania, Australia and revealed that the mean incidence of PVX increased during the season by $10.1 \%$ in one of the transet trials [94]. Muhammed, et al. assessed the prevalence of potato virus X (PVX) in samples of Cardinal, Diamond and Desiree cultivars, obtained from Sahiwal, Pattan and Faisalabad districts in Pakistan and reported that maximum incidence of PVX in samples from Diamont and Desiree [95]. Petrzik reported high incidence of PVX in south-west part of Czech Republic than north-east part on dock plants [69]. Effect of different climatic conditions on development of diseases was studied in India $[96,97]$ and concluded that high humidity with low temperature favoured PVX infection.

\section{Potato leaf roll virus}

\section{Geographical distribution}

Potato leaf roll virus (PLRV) is also known as potato phloem necrosis virus, Quanjer [24]. English names for the disease caused by PLRV are potato leaf roll, potato leaf curl and potato phloem necrosis or net necrosis. Freach-speaking people call the disease enroulement de la pomme de terre or feuilles en cuillere. Spanish names are enrollado de las jobas and arrollamiento de las bojas de la patata. German refer to the virus as Blattrollvirus and the disease as Blattrollkrankheit der Kartoffel. Rich told that this is one of the oldest and most serious of the virus disease of potato in New York (London) [30]. In India, PLRV was introduced by seriously infected potato while import and export $[98,99]$.

\section{Symptomatology}

Pushkarnath observed the thick, harsh, leathery and upward rolling of leaflects along with midrib which results small size tubers in infected plants [23]. Primary symptoms of PLRV appear mainly in young leaves at top of the plant with upright, pale-yellowish, purple or reddish and rolled characters while secondary symptoms are more serious than primary symptoms with stunted growth, rolled and leathery leaves [53]. Symptoms of primary infection appear mainly in young leaves at the top of the plants. These leaves are usually held upright and pale yellowish and in some cultivars tinged purple or reddish but symptoms of secondary infection are always more serious for the whole plant although they are less pronounced at the top of the plant than those of primary infection. The whole plant often looks, erect and may be smaller than a healthy one. Older leaves are rolled and higher leaves are pale. Ultimately infected potato plant show an upright of growth, stunting and a marginal yellow discoloration [100]. Peters and Jones [16] reported the primary symptoms on young leaves as upright rolling and slightly pale in colour and secondary infection as dry and leathery leaves, which results the stunted and rigid potato plant growth. In PLRV infected potato plants leaflets of the lower leaves roll up at edges and become somewhat papery, brittle and leathery to the touch and as the plant grows, the rolling appears on the higher leaves and eventually affects the whole plants. In some varieties, a reddish or purple discoloration occurs on the underside of the leaves which results the development of dwarfed and rigid potato plant $[30,101]$.

Plants grown from infected tubers are pale, dwarfed, more upright than normal and rolled leaves, especially the lower ones. Infected leaves are thick, leathery, brittle in texture, and crackle when squeezed in the hand. Symptoms first appear about a month after planting. Diseased plants produce fewer and smaller tubes than normal plants [30]. Infected plants are generally characterized by an upright growth habit and by leaves which are rolled and curl upward at the margin. Leaves are generally stiff, dry and leathery to the touch [78].

\section{Transmission}

Kennedy, et al. [102] and Beemster and Rozendall [43,44] identified several aphid spp. (Aphis nasturtii, A. fabae, Myzus ascalonicus, Macrosiphum euphorbiae) as vector of potato leaf roll virus (PLRV). PLRV can be artificially transmitted by stem by stem grafting and naturally by aphids only i.e. Myzus persicae [53]. Gibson describes that the disease associated with feeding by the aphid Macrosiphum euphorbiae for transmission [103,104]. Brien and Rich [28] and Rich [30] reported green peach aphid (M.persicae Sulfer) and infected tubers as source of PLRV transmission. Bacon, et al. and Peters and Jones reported that PLRV is successfully transmitted by Aphids (Nonpersistant) and grafting [16].

The PLRV is transmitted from plant to plants by green peach aphids (Myzus persicae) and other possible aphid vectors include the backthorn aphid (Aphis nasturtii), potato aphid (Macrosephum euphorbiae) and foxglove aphid (Acyrthosiphon solani) $[105,106]$. Van Hoff found that Phorodon humuli can transmit to PLRV [107]. Sigvald reported Neomyzus circumflexus as a vector of PLRV.PLRV can be artificially transmitted by stem grafting but is difficult to transmit by tubercore grafting [108]. In nature PLRV is transmitted to potatoes solely (Persistent manner) by aphids, of which Myzus persicae is the most efficient vector [84]. Beemster and De Bokx inoculated the PLRV by aphids and reported the stunting, chlorosis and some rolling in Physalis floridana, P. angulata and Datura stramonium plants [84]. Bhagabati, et al. conducted field experiments at Assam Agriculture University (India) in 1994-95 to investigate the natural incidence of potato leaf roll luteovirus (PLRV) in potato based intercropping system in Kufri Megha variety and concluded that the mean aphid vector population/ plant was lowest $(0.71 \%)$ and the final disease incidence was lowest (9.14\%) in the sole potato crop, whereas, the highest aphid population/ plant (1.13) with the highest disease incidence (28.5\%) occurred in the potato-wheat intercrop [109].

Roosen, et al. reported aphid (Myzus persicae) as vector of potato leaf roll virus (Potato leaf roll luteovirus) an concluded that inoculated plants may develop tubers expressing net necrosis at harvest or in storage [110]. Potato leaf roll virus (PLRV) is mainly transmitted through Myzus persicae and Aphis gossypii in persistent manner $[31,32]$. Slack reported aphids (Myzus persicae and Macrosiphum euphorbiae) as vector of PLRV [78]. Teulon and Stufkens investigated the relationship between activity of aphid virus vectors and PVRV 
incidence in seed potato crops using historical data and reported very low correlation coefficients between all variables (climate variables) [109]. Khurana and Singh reported that PLRV is the only potato virus that is transmitted in a persistant manner by $M$. persicae with the efficiency of $10-80 \%$ and nymphs of $M$. persicae and A. gossypii transmit PLRV more efficiently than adults [46]. Much of the spread of PLRV occurs in early summer (May to early July) and hence early appearance of $M$. persicae means greater infection of PLRV in potato crop [111,112]. The virus is transmitted through aphids, including Myzus persicae, M. assalonicus, M. ornatus, Macrosiphum euphorbiae, Brachycaudus helichrysi and Phorodon tumuli in persistant manner [38]. Agrios reported the aphid transmission of Luteovirus (PLRV) [39]. In nature PLRV transmission occurs through infected tubers and Aphids i.e. Myzus persicae, M. circumflexous, M. convolvuli, M. solanifollii and Aphis gassypii. Nymphs transmit the virus more efficiently than adults [42]. Kotzampigikis, et al. studied the aphid activity flight and the distribution of PLRV in experimental potato field and determined the infection of potato plants by PLRV by using DAS ELISA [113].

Zhang, et al. carried out trials in greenhouse and netroom to detect the resistant transgenic plants against potato leaf roll virus (PLRV) infected by aphids transmission and resulted that it is possible to develop potato varieties resistant to PLRV infection by transformation of potato plants with ribozyme genes [114]. Davis and Radcliffe reported that soybean aphid (A. glycines) transmitted PLRV from plant to plant with 6 to $9 \%$ efficiency [115].

\section{Host range}

Potato is the principle host of PLRV but the virus occasionally also attacks Lycopersicon esculentum, Solanum dulcamara, S. villosum, Datura stramonium, D. tatula, Physalis angulata and Physalis floridana [24]. Non solanaceous host plants include Amaranthus caudatus, A. graecizans, A. retroflexus, Celosia argentea, Gomphrena globosa and Nolana lanceolata [116]. Beemster and Rozendaal [43,44] told that Physalis floridana, P. angulata and Datura stramonium are commonly used test plants for PLRV tests. Physalis floridana and potato are the propagation hosts $[117,118]$. Peters and Jones [16] and Chiko and Guthrie [119] revealed that Physalis floridana is a suitable indicator, test and propagation host that reacts with interveinal chlorosis, darkening of the veinal areas and slight cupping at the first two or three true leaves, but Datura stramonium shows chlorosis in PLRV infected plants. Peters and Jones [16] and Pushkarnath [23] reported that the green-peach aphid $M$. persicae as a principal vector of the PLRV. Rich [30] and Khurana and Singh [31,32] reported PLRV from Datura stramonium and Physalis floridana as a cause of potato leaf roll virus disease. Plant Physalis floridana is a suitable indicator test and propagation host. Infected plants become stunted and develop systemic interveinal chlorosis. Datura stramonium also develops systemic interveinal chlorosis [78].

Kumar, et al. reported the systemic infection in D. stramonium L. and Physalis floridana Rydb [34-37]. plants. Savenkov and Valkonen studied the capacity of helper component proteinase (HC-Pro) to be a mediator of the synergism in mixed infections with potyviruses and luteoviruses in Nicotiana spp. and reported that PLRV accumulation in $N$. benthamiana is directly proportional to the concentration of the HC-Prof [120]. The virus can infect Datura stramonium, Datura tatula, Physalis tatula, Physalis angulata and Physalis floridana which are its differential hosts. The-solanaceous host include Celosia argentia, Gomphrena globosa, Nolana lanceolata, Capsella bursa-pectoris and Mentia perfoliata [42].

\section{Bio-physical property of virus}

De Bokx told that thermal inactivation point, dilution end point and In vitro longevity of PLRV are $70-80^{\circ} \mathrm{C}, 10^{-3}$ and $3-2$ days at $2^{\circ} \mathrm{C}$ respectively [53]. Thermal inactivation point is $70-80^{\circ} \mathrm{C}$, dilution end point is $10^{-3}$ and longevity in vitro is $3-5$ days at $2^{\circ} \mathrm{C}$ [84]. Tripathi reported that thermal inoculation point of the virus is $70-80^{\circ} \mathrm{C}$, dilution end point is $1 \times 10^{-4}$ and longevity in vitro is 5 to 10 days at $2^{\circ} \mathrm{C}$. Singh reported that thermal inactivation point of the virus is $70^{\circ} \mathrm{C}(10 \mathrm{~min}$.), dilution end point is $1: 10,000$ and in vitro longevity in the sap is 4 days at $2^{\circ} \mathrm{C}$ and $12-24 \mathrm{hr}$ at $25^{\circ} \mathrm{C}[38,42]$.

\section{Serological and nucleic acid based studies}

Maat and De Bokx [121] and Peters and Jones [16] used ELISA to detect the PLRV in tuber and other plant materials. Clarke used enzyme linked immunosorbent assay (ELISA) to detect the potato leaf roll virus [122]. Ambrosova, et al. generated and characterized the six hybridoma lines producing monoclonal antibodies for potato leaf roll luteovirus (PLRV) detection [123]. They also investigated the specificity of the interactions of the antibodies with 5 PLRV isolates and a heterologous luteovirus (barley yellow dwarf luteovirus). Seo, et al. extracted the RNA from potato leaves showing symptoms of PLRV by the use of AMES buffer in in vitro run-off transcription with the help of digoxigenin (DIG) and after hybridization labeled RNA found to PLRV RNA on the membrane was detected with anti-digoxigenin alkaline phosphate [124]. CSTD and 5-bromo-4-chloro-3-indolylphosphate/nitroblue tetrazolium (NBT) salt were used as a substrate for film exposure and colorimetric detection respectively. Thomas, et al. conducted a search to detect evidence for interactions between PLRV derived transgenes expressed in Russet Burbank Potato and viruses to which the transgenic plants were exposed and by which they were infected and concluded that viruses that were propagated in selected transgenic lines in a greenhouse were examined for similar alternations, transmission characteristics and serological properties were not altered when they replicated in potatoes containing CP constructs in the field or greenhouse [125]. Souza-Dias et al. compared the relatedness of Brazilian potato leafroll luteovirus (PLRV) isolates obtained from potatoes by polymerase chain reaction and reported that the Brazilian isolates were approximately $99 \%$ homologous with each other. They also suggested that the primer pairs utilized in this study could be used to detect PLRV (by RT-PCR) for diagnostic purposes and could be used to differentiate between PLRV isolates for epidemiological purpose [126].

Enzyme-linked immunosorbant assay (ELISA) and nucleic acid probes have been used to detect PLRV by Slack in year 2001. Akanda, et al. detected the incidence of potato leaf roll virus (PLRV) in foundation potato seed tubers obtained from different farms of Bangladesh by double antibody sandwich enzyme-linked immunosorbant assay (DAS-ELISA) and concluded that infection of PLRV in foundation seed tubers were beyond the tolerance level, $0.05 \%$ [127].

In India Krishna, et al. first time reported the coat protein sequence of PLRV (from Indian strain) to generate cDNA by using polymerase chain reaction (PCR). Xingquan, et al. amplified coat protein (CP) gene obtained from Fujian PLRV infected potato leaves by RT-PCR and reported that CP gene shared about 95\% homologus nucleotide sequence with other PLRV isolates in genbank [128]. Guo, et al. (2007) amplified one cDNA fragment (369 bp) of PLRV by reverse transcription polymerase chain reaction (RT-PCR) and compared with all the other 13 available PLRV isolates and showed that it had high homology with the other isolates, averaging 97.97\% [129]. 


\section{Morphology of virus particles}

Potato leafroll virus is small, isometric and measures about 24-25 $\mathrm{nm}$ in diameter [24] but according to De Bokx particles are polyhedral and $23 \mathrm{~nm}$ in diameter [53]. PLRV are isometric particles c. $24 \mathrm{~nm}$ in diameter and contain c. $28 \%$ of ssRNA [130]. Virus particles are isometric and about $25 \mathrm{~nm}$ in diameter [131]. Potato leaf roll virus particles of potato is isometric and $24 \mathrm{~nm}$ in diameter [84]. PLRV, a member of the family Luteoviridae, consists of iscosahedral particles, $24 \mathrm{~nm}$ in diameter having single standard RNA with $5.9 \mathrm{~kb}$ size. Khurana and Singh told that potato leaf roll virus is necrosis virus and has small, isometric virons measuring about $24-25 \mathrm{~nm}$ in diameter [31]. The virus particles are isometric in morphology, measuring about $24 \mathrm{~nm}$ in diameter $[38,39,42]$.

\section{Varietal screening}

Hassan, et al. studied during (autumn) 1992 and 1993 (summer) in cold store and at farmer field also and reported 72\% PLRV infection in cold store while at farmer field the infection $60 \%$ and Daska and $2 \%$. They also reported a high incidence of PLRV (48-72\%) in farmers own and Punjab seed [132]. Schuta and Lima studied the effect of infection by potato leaf roll luteovirus (PLRV) on the macronutrient content in potato plants and concluded that PLRV-infected plants had significantly lower contents of Nitrogen $(\mathrm{N})$, Phosphorus $(\mathrm{P})$ and Potassium (K) than uninfected plants [133]. Petr evaluated tetraploid potato clones, with presupposed resistance to potato leaf roll luteovirus during 1993-96 and concluded that a higher percentage of clones with relative resistance to potato leaf roll luteovirus can be expected with the use of parent 87.336, which originates from the Sante X A 61/2 crossing [134].

Yldrm, et al. conducted a two-year trial at Bozdag in order to select the progeny resistant to PLRV and found that Pilica $x$ (NY) (R24116), Bzura x Chipeta, Abnaki X NDA 2031-1, (NY) (R241-16) x (NY) (R247-1) and Abnaki x (NY) (R247-1) were resistant to PLRV [135]. In U.K. the potato leaf roll virus (PLRV) was reported 1840s as most common and main cause of potato degeneration [42]. Sher, et al. studied the incidence of PLRV in major potato growing areas of NorthWest Frontier Province, Pakistan and reported the highest incidence of PLRV 18\% in Peshwar and Dagbaisud, 23\% in Kalam and Ushu (Swat) and $9 \%$ in Rusa and Kalapul (Hozara) respectively [136]. Khan, et al. (2002) screened fifteen potato cultivars for their resistance to potato leaf roll virus in greenhouse and field experiments in Pakistan and concluded that cultivars 384636-1, FSD-Red, Desiree x Juse B, TPS9803, 384093-844 and TPS-9801 were moderately resistant to the plant viruses [88].

Primary symptoms are confined to top young leaves, which usually stand upright and turn, slightly pale/reddish/pink. Secondary symptoms on plant are characterized as pale, dwarfed and upright appearance with rolling of lower leaves than turn yellow, brittle and are leathery in texture [11]. Bostan, et al. studied the incidence of PLRV in potato cultivar Morfona in year 2004-05 and found 3.4\% infection in field condition [137].

Primary symptoms are more pronounced on apical leaves which are erect in appearance and look light green in colour. Virulent strains cause discolouration, severe leaf roll, stunting, phloem necrosis in stems and small size tubers [38]. Infected leaves are characterized by curling of leaflet margins inward, thick and leathery in appearance and internal tuber and stem necrosis was observed by Singh [42] on potato plant. Agrios revealed that PLRV cause a prominent upward rolling of the leaves and the plants are stunted and have a stiff upright growth in potato plants [39].

Chatzivassiliou, et al. studied the incidence of potato leaf virus (PLRV) and told that PLRV was widespread mainly in the upland crop in Xanthi (37.8\%) and Kilkis (30\%) and in non-certified seeds in pella (29\%) and also resulted that PLRV was restricted to cold mountainous regions [138]. Ali, et al. reported the $0.9 \%$ incidence of potato leaf roll virus in Syria [139]. Liu, et al. conducted a trial in China to study the yield and resistance of different potato cultivars and local landrace (CK) PLRV and observed that Zhongshu 2 and Favorita were susceptible to PLRV (11.90\%) [140].

\section{Potato virus $\mathrm{M}$}

\section{Geographical distribution}

Potato virus $\mathrm{M}$ (PVM) is found in potato cultivars worldwide including India, but it is probably more prevalent in eastern Europe and the former Soviet Union than in North America [141]. Tripathi reported that PVM disease is most popular in different parts of the world especially in Europe and North America [38]. Xu et al. reported PVM in Canada [79].

\section{Symptomatology}

Bagnall, et al. reported interveinal mosaic symptom of PVM in Irish Cabbler potato variety [142]. Mild strains of PVM evoke a mosaic between the veins of the leaflet tips and twisting of leaflets tips was also observed in potato plants [53]. Lee identified three strains of PVM in Taiwan with severe ordinary and mild symptoms [143]. According to Hiruki [17], Rich [30] potato virus $M$ cause severe and include mottle, mosaic, crinkling and rolling of leaves, stunting of shoots, leaflets deformation and twisting, necrosis of petioles and stems may develop in certain potato cultivars. Symptoms of potato virus M (PVM) on very young potato plants are twisting of leaflet tips and some rolling in top leaves. PVM inoculation in older plants does not cause any symptoms [84]. Chrzanowks and Zagorska mechanically inoculated a severe strain of PVM on 52 Polish potato cultivars and observed mild, moderate and severe symptoms [144].

According to German leaves of infected potato plants shows mittle, mosaic, crinkling, rolling and leaflet deformation which results the stunting of shoots and twisting followed by rolling of the tops [141].

Uniyal [11] reported that PVM may either be symptomless or may cause mosaic or paracrinkle in leaves. Tripathi told that symptoms of the disease include the appearance of mosaic, leaf curl, interveinal leaf mosaic and abnormal leaf crinkle [38]. Salamon isolated a mechanically transmitted flexuous plant virus approximately $650 \times 12 \mathrm{~nm}$ in size from woody nightshade (Solanum dulcamara) in Hungary and called as S. dulcamara strain [57]. He also reported the transmission of PVM virus through tubers and by Myzus persicae in a non-persistant manner, thermal inactivation point $\left(68-72^{\circ} \mathrm{C}\right)$, dilution end point $(10$ ${ }^{3}$ ) and crude sap remain virulent for 2-4 days at room temperature. Singh reported that PVM cause mosaic symptom on potato plants [42]. PVMcause mottle, mosaic, crinkling and rolling of leaves and stunting of shoots [79].

\section{Transmission}

Salaman and Le Pelley reported that grafts of King Edward scions infected with IVM to a species of Datura (D. tatula and D. bernbardii) incited a vein clearing followed by diffuse mottling and appearance of bright yellow spots [146]. Potato virus $M$ can be transmitted by 
mechanical inoculation. Aphid Myzus persicae can transmit the virus more readily than others [24]. Wetter and Volk succeeded in transmitting four isolates of PVM with $M$. persicae after 48 to $72 \mathrm{hr}$. feeding time [147]. PVM can be artificially transmitted by stem and tubercore grafting and natural spread in probably mainly by aphids (M. persicae, Macrosiphum euphorbiae and A. fragulae etc) [53]. Aphis gossypii frangulae, A. nasturtii, Aulacorthum solani, Macrosiphum euphorbiae and Myzus persicae are the vectors of PVM [43,100,148]. Hiruki [17] Khurana [32] told that most PVM strains are aphid transmissible in the non-persistant manner by Myzus persicae and less efficiently by Macrosiphum euphorbiae, Aphis frangulae and A. nasturtii.

PVM can be transmitted by sap inoculation, stem and tuber core grafting and aphids. Natural spread is probably mainly by aphid in the non-persistent manner. Aphis nasturtii is a better vector for PVM than M. persicae [84]. Potato virus $M$ can be transmitted by mechanical inoculation with infective sap and by tuber or stem grafting. Aphids (Myzus persicae, Macrasiphum euphorbiae and Aphis nasturtii) are also vector by PVM [141]. Potato virus M (PVM) is transmitted through aphids [11,42]. Tripathi reported that PVM is transmitted by aphids i.e. Myzus persicae. Other spp. of aphids are Aphis frangulae, A. nasturtii, Aulacorthum solani and Macrosiphum euphoribae [38]. Aphids are main vector of PVM in nature [39]. Marczewski, et al. derived the gene Gm from Solanum gourlayi and mapped at central region on potato chromosome IX and told after mechanical inoculation that Gm gene is responsible for the development of resistance against PVM [149].

\section{Host range}

Schultz observed the local lesions on $N$. debneyi, D. metel, Gaur and Cowpea incited by potato virus M $[150,151]$. He also reported that mix inoculation of PVS and PVM incited local lesions on D. bernbardii in between $18-20^{\circ} \mathrm{C}$. Potato virus $\mathrm{M}$ cause systemic chlorotic spots in D. metel, Ring like local lesion in $N$. debneyiii, irregular brown ring like local lesion in cowpea and necrotic streaking of the stem, petioles and leaf virus in Solanum rostratum plant [152,153]. PVM reacts with several types of symptom in different hosts like local chlorosis to necrosis in D. metel, necrosis in N. debneyii, systemic symptoms in Solanum rostratum and local necrosis in Vigna sinensis [53]. Hiruki, et al. [154] reported red kidney bean plant as important host of potato virus M. Beta vulgaris, Lycopersicon esculentum as host of PVM [155]. Ross found $L$. chilense as host of PVM [156]. Harrison includes Nicotiana debneyii, Chenopodium quinoa, Phaseolus vulgaris and Vigna sinensis as local lesion hosts [22]. Datura metel and D. stramonium are suggested as diagnostic hosts by Smith [24]. Kowalska and Was (1976) recommended L. chilense as the most reliable test plant for PVM. According to Hiruki [17] PVM cause local dark green or yellow spot in Chenopodium quinoa, local chlorotic rings or necrotic spots in Gomphrena globosa, local chlorosis or necrosis in Datura stramonium, systemic necrosis and stunting in Lycopersicon chilense, symptomless systemic infection in L. esculentum (tomato), systemic necrosis in Solaum rostratum, brown ringlike local lesions in $N$. debneyii, local necrotic lesions on primary leaves on Phaseolus vulgaris cv. Red Kidney and local brown necrotic lesions in Vigna sinensis plants. Potato virus M (PVM) develop different type of symptoms in different hosts i.e. systemic necrosis in $D$. metel, ring like necrotic lesion in $N$. debneyii, systemic symptoms in Solanum rostratum and local necrosis in Vigna sinensis [84]. Huttinga and Maat told that potato and tomato are good production hosts by PVM [59]. Grieco, et al. firstly recorded the natural infections of PVM in tomato in Apulia, southern Italy [157]. EPPO [56] Jeffries [158] and Verhoeven and Roenhorst $[56,57,159]$ reported that PVM can infect $N$. benthimiana, N. occidentalis, N. hesperis, Chenopodium amaranticolar and C. quinon plants. The PVS cause local dark green or yellow spots in Chenopodium quinon and local chlorotic rings or necrotic spots in Gomphrema globosa but local necrotic lesions on Phaseolus vulgaris cv. Red kidney [141]. Kumar, et al. [34] reported local symptoms in C. amaranticolar, C. quinoa, $N$. debneyiii and Phaseolus vulgaris $\mathrm{L}$. and systemic infection in Lycopersicon esculentum Mill. and N. occidentalis. Mosahebi, et al. detected PVM from 16 samples out of 57 varieties in potato growing areas of Iran by using ELISA, microprecipitation and gel diffusion and showed that PVM cause pinpoint necrotic lesion in French bean cv [160]. Red kidney and chlorotic lesion in Datura metel and Nicotiana debneyii. They also showed 11-19.5\% yield decrease in 3 cultivars tested.

Verhoeven et al. [159] mechanically inoculated the sap of Solanum jasminoides on test plant species, Chenopodium quinua, Nicotiana benthamiana, N. hesperis-67A and N. occidentalis-P1 and reported that $N$. hesperis-67A showed chlorotic local lesions and rugosity followed by vein necrosis and $N$. occidentalis-P1 showed necrotic local lesions and systemic leaf distortion. They also identified the potato virus $\mathrm{M}$ (PVM) by double antibody sandwich enzyme-linked immunosorbent assay using leaves from S. jasminoides and N. hesperis-67A.

\section{Bio-physical properties of virus}

Potato virus M (PVM) belongs to genus carlavirus. Schultz placed the sap of PVM infected plants and inoculated on indicator plants (Datura metel) and reported that the sap was infective upto four days and produced local and systemic spotting [151]. De Bokx [53] and Beemster and De Bokx [84] reported that thermal inactivation point, dilution end point and longevity in vitro are $65-70^{\circ} \mathrm{C}, 10^{-2}$ to $10^{-3}$ and 2-4 days respectively. Thermal inactivation point, dilution end point and infectivity of PVM are $65-70^{\circ} \mathrm{C}, 10^{-2}$ to $10^{-4}$ and $2-4$ days at $20^{\circ} \mathrm{C}$ [17,154,161]. Tripathi [38], Agrios [39] and Singh [42] reported that thermal inactivation point, dilution end point and longevity in vitro of PVM are 65 to $71^{\circ} \mathrm{C}, 10^{-2}$ to $10^{-3}$ and several days at $20^{\circ} \mathrm{C}$, respectively.

\section{Serological and nucleic acid based studies}

Bagnall, et al. [152] and Kassanis [162] reported the precipitation end point of PVM is about $1 / 64$ and used chloroplast agglutination test for identification. De Bokx, et al. detected PVM by using ELISA in foliage as well as in dormant and sprouted tubers [163]. German in 2001 used enzyme linked immunosorbent assay (ELISA) for detection of PVM from infected samples [141]. Faccioli and Colombarini [164] used DotELISA to observe that \% of PVM-free plantlets obtained by meristem tip culture and reported the 69 and $68 \%$ virus free progenies. Garg, et al. [111] detected the presence of PVM from infected leaves of potato cultivars Saco and Green mountain by solid and liquid phase immunoelectron microscopy (SPIEM) with the help of different combination of buffer/antiserum (i.e. 8.0/7.0, 8.0/8.0 and 7.0/6.0). Flakten develop a full length cDNA clone of potato virus M (PVM) from total RNA extracted from infected Nicotiana hesperis plant by using RT-PCR and inoculated in different hosts plant to study the symptoms undistinguished from those caused by wild type PVM [165]. Xu, et al. reported that currently enzyme-linked immunosorbent assay (ELISA) is the predominant method employed for the detection of PVM in potato sample on large scale [79]. They also told that reverse transcription polymerase chain reaction (RT-PCR) have been developed and employed successfully for the specific detection of several potato viruses including various strain of groups of viruses including PVM. Oligonucleotide primers specific to PVM CP gene were designed for PVM identification by them. Restriction fragment length polymorphism (RELP) was introduced to verify PCR amplicon identity. 


\section{Morphology of virus particles}

PVM particles are straight to slightly flexous rods $(650 \times 12 \mathrm{~nm})$ $[17,154,161]$. Morphologically potato virus $M$ particles are slightly flexible rods and measuring $650 \times 12 \mathrm{~nm}$ in size [53,84]. PVM is a member of genus carlavirus. Its virions are slightly flexous rod shaped particles $(12 \times 650 \mathrm{~nm})$, composed of multiple copies of a $34 \mathrm{kDa}$ oat protein and monopartite ssRNA stand [141]. The virus particles are elongated, measuring about $650 \times 12 \mathrm{~nm}$ in size $[38,39,42]$.

\section{Varietal screening}

Agur evaluated potato varieties i.e. Ants, Berber, Lazunak, Prigozil 2, Procura, Sante, Sarme, Timate and Varajane Kollane for the resistance of two isolates of potato $\mathrm{M}$ carlavirus (PVM) and observed the highest resistance to both isolates and PVM in Ants and Procura cultivars [87]. In India Shiv, et al. [166] tested seed stocks of nine potato cultviars Kufri Bahar, Kufri Jyoti, K. Chandramukhi, K. Sutlej, K. Lalima, K. Sindhuri, K. Badshah, K. Pushkraj and K. Anand for the presence of potato virus $\mathrm{M}$ (PVM) using both leaf and srout samples by alkaline phosphate enzyme DAS-ELISA and resulted that PVM incidence ranged from 1.1 to $16.6 \%$ and highest incidence (16.6\%) was recorded for K. Badshah, K. Bahar, K. Jyoti, K. Sutlej and K. Sindhuri. Abou, et al. reported the incidence of PVM in potato fields in Lebanon [167]. In UK, PVM incidence was reported by Brunt [168]. Zagorska and Chrzanowska estimated the reaction of 196 potato cultivars to potato virus M (PVM) in Poland and reported that 3 Polish cultivars, i.e. Triada, Korona and Kuklik showed outstanding resistance to PVM infection [167]. They also told that only $25 \%$ of the cultivars were severely infected with PVM. Liu, et al. screened the potato cultivars and reported that Zhongshu 3 was susceptible to PVM with $23.81 \%$ incidence [140].

\section{Potato virus S}

\section{Geographical distribution}

Potato virus S (PVS) is one of the most common viruses of potato worldwide [141]. PVS is present worldwide, whereas $\mathrm{PVS}^{\mathrm{A}}$ has been reported from Andean region of South America, Germany, Netherland, New Zealand, USA and India [34], Japan [139], China [170], Pakistan [95] and in Poland by Janczur, et al. [171].

\section{Symptomatology}

Bagnall told that PVS first cause slight deepening of veins, rugosity of leaves and growth stunting then necrotic spots in later stage in potato plant typical symptoms of PVS vary with strains and weather [172]. Deepening of veins on the upper side of leaves and mild rugosity is commonly seen but in some varieties slight or distinct mottle and sometimes faint banding of veins is also observed [53]. The symptoms of PVS in certain potato cultivars may develop a mild mosaic and tiny necrotic spots on the abaxial surface [22,24,126,174]. Rich [30] and Khurana and Garg [31] reported that potato plant infected with potato virus S (PVS) shows mild, imperceptible mottling of leaves followed by chlorosis and stunting of plants. In many cultivars PVS evokes mild rugosity, slight pendulousness of leaves and slight or distinct mottling in potato plants $[141,174]$. Slight or distinct mottle and sometimes faint vein banding was observed by Kumar, et al. [35] due to PVS infection in potato cultivars. Potato virus S (PVS) belongs to carlavirus group and cause very mild symptom of mosaic on hosts $[11,38,39,42,79]$.

\section{Transmission}

Kohler of Germany in 1953 told that virus S of Fortuna potato incited localized chlorotic spots on G. globosa plants after sap inoculation. Dykstra [175], Bawden, et al. [176] Ouboter [174], Rozendaal and Kassais reported that PVS virus from King Edward potato was transmissible to tomato. Potato virus $S$ is transmitted easily by mechanical inoculation with infectious sap. It spreads naturally in the field by leaf contact. Animals, machinery and man may also spread it from plant to plant in the field $[22,28]$.

PVS can be transmitted not only by stem grafting, tuber-core grafting, sap inoculation and contact between infected and healthy plants but also by aphids (some Andean strains) [30]. Certain strains of PVS are transmitted by the aphid (Myzus persicae) in non persistant manner [31,172]. PVS can be transmitted by stem grafting, tuber-core grafting, sap inoculation and by contact between infected and healthy plants [53,141]. Khurana and Singh PVS (Carlavirus) is transmitted by aphids in non-persistent manner [34]. According to Kumar, et al. PVS are readily transmitted by aphids including A. fabae, A. nasturtii, M. persicae and Rhopalosiphum padi in non-persistent manner [35]. In nature the virus is transmissible mechanically through infective plant sap. Aphids usually transmit the virus non-persistently. Aphis nasturii is the most efficient vector among several species [38]. Agrios reported the aphid transmission of PVS [39]. The PVS is transmitted through mechanical inoculation and by insects belonging to family aphididae (Myzus persicae) (www.ncbi.nlm.nih.gov/IVTVdb/ ICTdB/index.htm).

\section{Host range}

Matousek, et al. studied 34 isolates including 15 PVS-CS variants and revealed that these isolates cause systemic infection in Chenopodium quinoa [177].

Wetter and Brandes [178] reported that the virus they had transmitted to tomato and which incited local lesion on G. globosa was an 'aberrant strain' of virus S. Schultz $[150,151]$ observed the systemic vein clearing and mottle on $N$. debneyii and local lesions on guar incited by potato virus S. De Bokx reported N. occidentalis, N. rosulate, N. rotundifolia and N. velutina as symptom less host of PVS [179]. De Bokx in 1972 reported that PVS cause local lesions in Chenopodium quinoa, C. amaranticolar and G. globosa and vein clearing in N. debneyii but Solanum rostratum shows systemic symptoms [53]. Kowalska and Was reported potato as natural host and Chenopodium quinoa and leaves of Solanum demissum as indicator host [99]. Bagnall and Larson listed Chenopodium album, Cyamopsis tetragonoloba, N. debneyii, Saracha umbellata and Solanum rostratum as hosts which produced characteristic symptoms [173]. They also listed Physalis Philadelphia, D. metel and Solanum villosum as symptomless hosts. Kowalska found that PVS produced minute lesion lesions on Phyaseolus vulgaris cv. Red Kidney 5 days after inoculation [180]. Ksiazek recorded Chenopodium album as a weed host [181]. Bagnall reported that PVS cause systemic vein clearing in Nicotiana debneyii, necrotic spots in Solanum rostratum and Saracha umbellate, symptom less systemic infection in Datura metel, Physalis philadelphica and P. pubescens and local lesions in Chenopodium album, C. amranticolar and in Cyamopsis tetragonoloba plants [172]. Potato is the usual production host of PVS [59]. N. benthimiana, N. occidentalis, N. Hesperis, Chenopodium amaranticolar and C. Quinon are hosts of PVS [56,57,158]. The PVS isolates from North America and Europe induce a local lesion response in Chenopodium quinoa, C. album and C. amaranticolar [141]. PVS induces local lesions on C. amaranticolar, C. quinoa, C. album, C. murale, C. Hybridum, C. Ambrosiodes, C. rubrum and C. Opulifolium, necrosis and leaf chlorosis in Nicotiana occidentalis and reddish local lesions on G. globosa plants [34,35]. 


\section{Bio-physical properties of virus}

Potato virus S (PVS) belongs to carlavirus group having thermal inactivation point, dilution end point and longevity in vitro $55-60^{\circ} \mathrm{C}$, $10^{-3}$ and 4 days at $20^{\circ} \mathrm{C}$ respectively $[51,172,174]$. Kohler reported the thermal inactivation point of Dutch virus $\mathrm{S}$ in between 68 and $71^{\circ} \mathrm{C}$ [182]. De Bokx [53] told that thermal inactivation point of PVS is $55-60^{\circ} \mathrm{C}$, dilution end point is $10^{-3}$ and in vitro longevity is $2-3$ days. Thermal inactivation point of the PVS virus is $55-60^{\circ} \mathrm{C}$, dilution end point is $1 \times 10^{-2} \times 10^{-3}$ and longevity in vitro is $3-4$ days at $20^{\circ} \mathrm{C}$ [38].

\section{Serological and nucleic based studies}

Bagnall and Larson recognize strains of PVS by polyethylene glycol addition in precipitation test [173]. Potato virus $S$ is serologically active and agglutination test are preferable to gel diffusion tests, possibly due to the large particle size. The precipitation end point is about 1/64 [22]. Joung, et al. detected PVS strains (PSVO, PSVA) in potato cv. Shepody, Desiree by using ELISA and RT-PCR and also reported the length of PVS particle $650 \mathrm{~nm}$ by transmission electron microscope [183]. Ptacek, et al. used RT-PCR and cDNA hybridization for the detection of PVS in lab [184]. Garcia, et al. regenerated the potato plants by meristems (0.2-0.3, 1.1-0.2 and 0.06-1.00 mm) in MS media and diagnosed for the presence of PVS by using ELISA and reported that plants regenerated from 0.06 to $1.00 \mathrm{~mm}$ meristems were $96 \%$ virus free [185]. PVS is strongly antigenic and enzyme-linked immunosorbent assay (ELISA) is a convenient and reliable assay for diagnosis [141]. Li, et al. amplified total RNA of PVS obtained from diseased potato leaves by using RTPCR and reported molecular size of PSV about 33 KD [186]. Mosahebi, et al. collected 1818 samples of potato plants showing infection of viruses in Iran and tested the samples for PVS infection using DASELISA and revealed that the thermal inactivation point, dilution end point and in vitro longevity were $55-60^{\circ} \mathrm{C}, 10^{-3}$ and $3-4$ days, respectively [71]. Wu, et al. identified the potato virus S (PVS) in the main potato growing area of Fujian province, China. Based on the identification and electron microscope and assay hosts and detected PVS by the improved one step RT-PCR and nucleic acid spot hybridization (NASH) [82]. Janczur, et al. used ELISA test to identify the PVS in potato plantlets propagated by tissue culture technique [171]. Lang, et al. obtained an isolate of potato virus S (PVS), HZ00P1 and identified by DAS. ELISA from naturally infected Solanum tuberosum from Hangzhou Zhejiang province, China and also revealed $26.7 \%$ infection of PVS in Zhejiang province [170].

\section{Morphology of virus particles}

Wetter and Brandes studied the virus $\mathrm{S}$ under electron microscope and revealed that the virus particles are rod shaped and 650-675 nm in length [187]. Wetter in year 1971 also reported that PVS particles are straight to slightly curved filamentous particles, $650 \times 12 \mathrm{~nm}$, helically constructed. Potato virus $\mathrm{S}$ particles are straight to slightly curved filaments approximately $650 \times 12 \mathrm{~nm}$ in size [172,174]. Brandes, et al. [153], Harisson [22] reported particles as $652 \times 12-13 \mathrm{~nm}$ in size while De Bokx [179] claimed that PVS particles varied from 641 to 655 $\mathrm{nm}$. PVS is a member of genus carlavirus having slightly flexuous rodshaped particles with $12-13 \mathrm{~nm}$ in diameter and 610-700 nm length [141]. According to Kumar, et al. [135] PVS (carlavirus) particles are rigid to flexible filaments having $650 \times 12 \mathrm{~nm}$ size. The virus particles are elongated, usually measuring about $650 \times 1 \mathrm{~nm}$ in size [38,39].

\section{Varietal screening}

Dedic, et al. investigated the presence of potato virus S in 209 genotypes from imported and domestic potato and found $12 \%$ material was infected [188]. They further evaluated the 124 potato cultivars during 1994 and 1995 and reported that $4 \%$ and $7 \%$ samples were fully infected. Urbanaviciene separated and identified the twenty isolates of PVS and showed that typical strain of PVS was widely spread in potato fields of Lithuania [189]. Mosahebi, et al. collected the 1818 samples and tested the infection of PVS by using DAS-ELISA and reported the average infection of PVS varied from 0 to $100 \%$, thermal inactivation point, dilution end point and in vitro longevity were $55-60^{\circ} \mathrm{C}, 10^{-3}$ and 3-4 days respectively [75]. Xingquan, et al. identified and detected the 14 PVS isolates with the help of EM and assay hosts and reported that PVS is widely distributed in Fujian with highest disease rate of PVS i.e. 80\% [190]. Bostan et al. reported the 5.3\% incidence of PVS in Morfona cultivar of potato in year 2004-05 [137]. Baldauf, et al. made survey of six potato viruses in year 2002 and 2003 and reported that in both years, PVS and identified in a majority of the samples and mixed infections predominated in a majority of the samples [191]. Janczur, et al. reported the presence of PVS in potato plantlets [171]. Muhammad, et al. reported the incidence of PVS in Satiwal, Pak Pattan and Faislabad districts in Pakistan [95]. Lambert, et al. studied the spatial and temporal distribution of potato virus S (PVS) in two trial in potato var [94]. Russet Burbank in Australia and reported that the mean incidence of PVS increased by $5.2 \%$ and $25.5 \%$ in both trials respectively. Ali, et al. reported the $8.4 \%$ incidence of PVS in Syria and detected the virus by using ELISA and PCR [139]. They also reported PVS infection in Chenopodium amaranticolar plant. Liu, et al. screened the potato cultivar and found $47.62 \%$ incidence of PVS in different cultivars [140].

\section{Ecofriendly management}

Verma, et al. [192-194] and Verma and Awasthi [195-197] conducted experiments with antivirus substance of plant origin and found considerable reduction in infection by the viruses. Later on Awasthi and Mukerjee found protection of potato virus infection by extract from some medicinal plants [198]. The control of virus disease of some cucurbitaceous crop was reported also by the same group [199]. Verma et al. reported that dry fruit pericarp of Terminalia chebula Retz [200] brought about hundred per cent inhibition of potato virus $\mathrm{X}$ (PVX) in vitro and in vivo. Yukawa, et al. reported that tannins from Terminalia chebula Retz [201] is effective to reduce the infectivity of potato virus X (PVX). Awasthi, et al. observed that pre-inoculation sprays of Boerhaavia diffusa root extract were effective against tobacco mosaic virus in tobacco, cucumber mosaic virus and TMV in tomato, cucumber green mottle mosaic virus in melon, sunnhemp rosette virus in Crotolaria juncea and Gomphrena globose [202]. Verma, et al. suggested possible control of natural infection of mungbean yellow mosaic virus in mungbean and urdbean by plant extracts [203]. The infection of MYMV on these crops was suppressed by aqueous, partially clarified leaf extract of Clerodendrum aculeatum and root extract of $B$. diffusa [204-206]. The treatments were administered as foliar sprays since seedling stage.

Prevention of oat sterile dwarf virus infection and suppression of disease symptoms was observed by some phytochemicals [207]. Verma and Verma [208] revealed that leaf extract of C. aculeatum (CA) along with soil amendment of the its dry leaf powder showed two folds increase in nodulation and grain yield with 50 per cent reduction in disease incidence caused by mungbean yellow mosaic virus. Verma and Singh reported that the C. aculeatum as a possible prophylactic agent against natural viral infection in mungbean plants [209]. The plants raised in pots and kept in the field, were protected against natural viral infection by spraying with leaf extract of $C$. aculeatum, together 
with soil amendment with dry leaf powder or fresh extract. Unsprayed plants showed severe symptoms while treated plants were either a symptomatic or showed only very mild symptoms. Soil treatment with dry leaf powder + sprays with fresh leaf extract were effective in increasing the yield as well as reduced disease incidence and severity.

Verma, et al. observed the efficacy of leaf extracts of different species of Clerodendrum [209]. When applied to leaves of several hypersensitive hosts prevented infection of viruses by increasing the resistance of the host plants. The numbers of local lesions produced on treated leaves were much lower as compared to untreated leaves. The decrease in lesions number by different species of Clerodendron was variable. Verma and Varsha used Clerodendron aculeatum (CA) alone and with certain proteinaceous modifiers (CA-M) against sunnhemp rosette virus (SHRV) in Crotolaria juncea and observed that in CA-M (with papain) sprayed plants, disease incidence was only 7 per cent when treated plants were challenged with SHRV 6 days after the treatments [210]. Verma, et al. purified a non-phytotoxic systemic resistance inducer from $C$. aculeatum leaves [211]. A specific basic protein (Cleroderdon aculeatum- systemic resistance inducing, CaSRI) with a molecular weight of $34 \mathrm{kDa}$ was observed by SDS-PAGE. It induced more than 90 per cent of local lesions.

The prevention of tomato yellow leaf curl vector borne virus was checked significantly by the application of $B$. diffusa root extract [212]. Jayashree, et al. [213] studied the efficacy of 10 plant extracts against pumpkin yellow vein mosaic virus in pumpkin and showed maximum inhibition of virus transmission by Bemisia tabaci by Bougainvillea spectabilis followed by $B$. diffusa. Surendran, et al. observed the antiviral activity of plant extracts (Azadirachta indica, Clerodendron infortunatum, Ocimum sanctum, Vitex negundo) against brinjal mosaic virus on local lesion host Datura stramonium [214]. The preinoculation sprays of 10 per cent leaf extract or oil formulations of $A$. indica was found effective in reducing the number of local lesions and their efficacy against the virus under field conditions. Jimenez and Agramonte [215] revealed that the chemical control did not prevent the movement of winged aphids from plant to plant, thereby allowing PRSV transmission. The plant hopper population was reduced however top infested plants were still present. The chemical control of insect vectors was not efficient in avoiding disease transmission.

Neem (Azadirachta indica) was evaluated as a potential component in the integrated management of papaya for its ability to delay incidence and reduce severity of papaya ring spot virus. Three integrated management based treatments were included, aqueous extracts of need seeds 55 (MIP + Nim 5\%), 2.5 per cent (MIP + Nim 2.5\%) and no neem (MIP Sin Nim). No significant differences among treatments were found on PRV incidence and severity and estimated yield. MIP + Nim 2.5 per cent were also compared with two commercial papaya groves: one grove used all management elements of MIP (TEST-MIPC); the other used traditional regional management practices (TEST-REG). 170 days after transplant MIP + Nim 2.5 per cent, TEST-MIP and TEST- REG reached PRV incidence of 22, 40 per cent and 100 per cent, respectively and severity at the same period was 7, 22 and 57 per cent, respectively [216].

Singh [217], Singh and Awasthi [218] and Chaube, et.al. [219,220] reported that aqueous extract of a few higher plants effectively reduced mungbean yellow mosaic and bean common mosaic virus disease in mungbean and urdbean, PVX in potato and chilli mosaic virus in chilli, alongwith increased grain/tuber /fruit yield in field condition. Lateron Awasthi and Kumar, Kumar and Awasthi [36,37], revealed that weekly sprays of aqueous root extract of $B$. diffusa significantly prevented infection, multiplication and spread of cucumber mosaic virus, bottle gourd mosaic virus, cucumber green mottle mosaic virus, pumpkin mosaic virus in cucurbitaceous crops.

Singh, et al. [221], Singh and Awasthi [93], Singh, et al. [222] and Singh and Awasthi [223] reported the prevention of yellow mosaic disease of mungbean and urdbean by clarified aqueous root extract of $B$. diffusa. Six sprays of $B$. diffusa root extract (10\%) could reduce 80 90 per cent disease incidence and increased nodulation, plant height primary and secondary branches, pod formation and grain yield. Awasthi and Singh [224] reported that most effective treatment was seed treatment with $B$. diffusa root extract + three foliar spray which exhibited 65.36 per cent reduction in disease incidence followed by seed treatments with C. aculeatum leaf extract + three sprays.

Modulary effect of phytoproteins isolated from the root extract of B.diffusa and leaf extract of C.aculeatum, against animal viruses, was studied by Singh, et al [206]. They found significant reduction in the infection of virus on neoplastic growth of human breast cancer cell line. The molecular studies on the virus inhibitory agent induced in different hosts following the treatment with $B$. diffusa root extract [225-227]. and the possible mode of action of phytoproteins was also studied [228,229].

A successful beginning towards the ecofriendly management of viral diseases of different crops could also be achieved [77,97,230235]. Immunization by plant products that stimulate the plant's natural disease resistance mechanism may provide a new strategy for crop protection against viruses. By using certain modifiers/ spreaders and micropropogating the plants of $B$. diffusa on suitable modified MS medium, the antiviral activity has been markedly improved and prolonged. Thus, a modest beginning towards successful virus control has been made [236-242].

\section{References}

1. Panday SK, Sarkar D (2005) Potato in India: Emerging trends and challenges in the new millennium. Potato J 32: 93-104.

2. Naik PS, Thakur KC (2007) Potato in India; an overview. Potato production and utilazion in India 26th biennial group meeting of AICRP on potato, held at RAU Pusa Bihar pp. 7-12.

3. http://www.potato2008.org/en.index.html

4. Chadha KL (2002) Potato Hand Book of Agriculture. pp. 492-498.

5. Marwaha RS, Sandhu SK (1999) Processed products from potato. Indian Farming 49 31-38.

6. Shekawat GS, Dhaiya PS (2000) A neglected major food crop. The Hindu Survey of Indian Agriculture, (Annual), Chenni pp. 73-76.

7. Shekhawat GS, Naik PS (1999) Importance of potato. Potato in India. Malhotra Publishing House, New Delhi pp. 9-20.

8. Shekhawat GS, Naik PS (1999) Potato in India. Technical Bull. No. 1, CPRI. Shimla pp. 1-28.

9. Pathak SP, Verma RB (2009) Potato in Uttar Pradesh. Region specific technology for potato production in India. Naik PS, Lal SS (Eds) Potato technology bulletin No. 3 CPRI, Shimla.

10. Mahendra KR (1930) Virus disease of potatoes in Punjab. Proc 17th Indian Sci Congr pp. 56 .

11. Uniyal JP (2003) Production and utilization of True Potato Seeds (TPS). In: Potato cultivation in North Eastern India. Singh PH, Chandla PH, Paul Khurana SM, Garg ID, Thakur KC, et al. (Eds) Central Potato Research Institute, Shimla pp. 11-23.

12. Paul S, Konar A (2003) Integrated pest management of aphids of potato in gangetic plains of West Bengal. Proc. Recent Environ. Changes, Impact on Health, Agriculture and Ecosystem. Santa SC (Ed), Univ. Kalyani, WB pp. 26-29.

13. Nagaich BB, Shekhawat GS, Khuran SM, Bhattacharya (1974) Pathological problems of potato cultivation in India. J Indian Potato Asso 1: 32-44. 
14. Khurana SMP, Singh MN (1988) Yield loss potential of potato virus X and Y in Indian potatoes. J Indian Potato Assoc 15: 27-29.

15. Khurana SMP, Garg ID (1992) Potato mosaic. In Plant disease of international importance. Disease of vegetable and oilseed crops Chaube HS, Singh US, Mukhopadhay AN, Kumar J (Eds), Prentice Hall, New Jersey, USA pp. 148-164.

16. Peters D, Jones RAC (1981) Disease in the presence of infectious pathogen. In. Compendium of Potato Disease, WJ Hooker (Ed) Am Phytopathol Soc pp. 27-90.

17. Hiruki C (1981) Disease in the presence of infectious pathogen. In: Compendium of Potato Diseases Hooker WJ (Ed) Am Phytopathol Soc pp. 27- 90.

18. Munro J (1961) The importance of potato virus X. Am Potato J 38: 440-447.

19. Tamada T, Harrison BD (2008) Quantitative studies on the uptake and retention of potato leafroll virus by aphids in laboratory and field condition. Ann App Bio 98: 261-276.

20. Konar A, Singh NJ (2009) Occurence of aphids on various potato germplasms in eastern gangetic plains of West Bengal. J Pl Prot Sci 1: 21-24.

21. Smith KM (1931) On the compsite nature of certain potato virus diseases of the mosaic group as revealed by the use of plant indicators. Proceedings of the Royal Society, London Bulletin 109: 251-267.

22. Harrison BD (1971) Potato virus in Britain. In: Diseases of crop plants Western JH (Ed). Wiley, New York pp. 123-159.

23. Pushkarnath (1964) Plant characters and their range of variability. In Potato in India Kachroo P (Ed), Indian Council of Agricultural Research, New Delhi pp. 21-27.

24. Smith KM (1972) A handbook of plant virus diseases, (3rd Edn) Academic Press, New York.

25. Johnston GR, Rowberry RG, Mainprize LE (1970) York, an early potato blight in potato solids and adopted to organic soils. Am Potato J 47: 201-204.

26. Maurer AR, Adrichem MV, Young DA, Davies HT (1968) Cariboo, a new late potato variety of distinctive appearance. Am Potato J 45: 247-249.

27. Rich AE (1977) Potato disease. In: "Potato: Production, storing, processing (2nd Edn) (Ed) Smith O. Avi Publication, West Port, Connecticut pp. 506-549.

28. Brien MJO, Rich AE (1976) Viral diseases and Mycoplasms. Potato Diseases. Agriculture handbook 474: 44-69.

29. Sharma K, Uniyal JP, Chandla P (1982) Pests and their control. In Potato in India, Bul-1 Nagaich BB (Ed) New Printers, Shimla pp. 27-28.

30. Rich AE (1983) Diseases caused by viruses, viroids and mycoplasms. Potato diseases. Academic Press, London pp. 92-135.

31. Khurana SMP, Garg ID (2000) Potato Mosaic. In: Diseases and Pests of Potato SM Paul Khurana (Ed) Manual pp. 36-40.

32. Khurana SMP, Singh MN (2000) Potato leaf roll. In: Diseases and Pests of Potato (Ed) Paul Khurana SM Manual. pp. 33-35.

33. Jung H, Yun W, Seo H, Hahm Y, Kim K (2000) Characterization and particle nucleotide sequence of potato virus $\mathrm{X}$ isolated from potato in Korea.

34. Kumar S, Garg ID, Khurana SMP (2003) Biological and serological diagnosis of potato viruses. In: The potato production and utilization in sub-tropics. Paul Khuraa SM, Minhas JS, Pandey SK (Eds) Mehta Publication, Naraina II, New Delhi pp. 238-245.

35. Kumar S, Singh MN, Khurana SMP (2003) Contact transmitted viruses. In: The Potato, Production and Utilization in sub-tropics. Paul Khurana SM, Minhas JS, Pandey SK (Eds) Mehta Publication, Naraina II. New Delhi pp. 230-237.

36. Kumar P, Awasthi LP (2003 a) Prevention of Cucumber mosaic virus infection and spread in cucumber plants, treated with Boerhaavia diffusa inhibitor. Indian Phytopath 56: 318.

37. Kumar P, Awasthi LP (2003 b) Management of infection and spread of bottle guard mosaic virus disease in bottle gourd through botanicals. Indian Phytopath 56: 361 .

38. Tripathi DP (2004) Virus diseases of industrial plants. Introductory plant virology. Kalyani Publication, New Delhi pp. 303-343.

39. Agrios GN (2005) Properties of plant viruses. Plant Pathology, Academic Press, London pp: 724-820.

40. Bawden FC (2006) External symptoms of infected plants. Plant viruses and virus diseases. Chawla Offset Printers, New Delhi pp. 1-35.

41. Bawden FC (2006) Methods of Transmission. Plant viruses and virus diseases. Chawla Printers, New Delhi. pp 37-56.
42. Singh RS (2006) Virus and viroid diseases of plants. Plant Disease. Oxford and IBH Publishing Co. Pvt. Ltd. New Delhi pp. 539-585.

43. Beemster ABR, Rozendaal A (1972) Potato viruses: Properties and symptoms. In: De Bokx JA (Ed) Viruses of potatoes and seed-potato production. Pudoc, Wageningen. pp. 115-143.

44. Beemster ABR, Rozendaal A (1972) Potato viruses: properties and symptoms. In Viruses of potatoes and seed-potato production de Bokx (Ed) JA. Podoc, Wageningen, Netherland. pp. 115-142.

45. Munro J (1981) Disease in the presence of infectious pathogen. In: Compendium of Potato Diseases (Ed) Hooker WJ. Am Phytopathol Soc pp. 27-90.

46. Khurana SMP, Singh MN (2003) Vector and true seed transmitted viruses. In: The Potato-Production and utilziation in sub-tropics Paul Khurana SM, Minhas JS, Pandey SK (Eds) Mehta Publication, Naraina, New Delhi pp. 221-229.

47. Damadi SM, Mosahebi GH, Okhovvat M (2005) Purification of potato virus X and preparation of its antiserum. Commun Agric Appl Biol Sci 70: 427-429. [Crossref]

48. Silva OA, Figueira AR, Boari AJ, Pinto CABP, Boni RR (2005) Biological characterization of the PVX isolates (potato virus X) from Brazil. Ciencia-eAgrotechnologia 29: 521-527.

49. El-Muadhidi MA, Habib SA (2006) Presence of potato virus $\mathrm{Y}$ and potato virus $\mathrm{X}$ in wright ground weed (Physalis wrightii, Gray) in Iraq. Arab J Pl Pro 24: 84-88.

50. Fribourg CE, Zoeten GA de (1975) Some leguminous hosts for potato virus X. Pl Dis Rep 59: 923-925.

51. Wetter C (1971) Potato virus S No 60. In. Descriptions of plant viruses. Commonw Mycol Inst Assoc Appl Biol, Kew, Surry, England.

52. Willis CB, Larson RH (1960) A new host for potato virus X in the Leguminosae. Phytopathology 50: 659 .

53. De Bokx, de JA (1972) Test plants. Viruses of potatoes and seed-potato production. Podoc. Wageningen. Netherland pp. 102-110.

54. Dijk PV, Vander FAM, Piron PGM (1987) Accessions of Australia Nicotiana species suitable as indicator host in the diagnosis of plant virus disease. Netherlands J Pl Pathol 93: 73-85.

55. Dijk PV, Cuperus C (1989) Reactions of Nicotiana species to potato virus A, X and $\mathrm{Y}$ and tobacco mosaic virus in relation to their taxonomy and geographical origin. Netherlands J Pl Pathol 95: 343-356.

56. Verhoeven JTJ, Roenhorst JW (2000) Herbaceous test plants for the detection of quarantine viruses of potato. EPPO Bull 30: 463-467.

57. Verhoeven JTJ, Roenhorst JW (2001) Herbaceous test plants for the detection of quarantine viruses of potato not transmitted via true seeds. 11th EAPR virology section meeting. Czech Republic pp. 53-55.

58. Bercks R (1970) Potato virus X. CMI/AAB Description of Plant Viruses 4: 4.

59. Hutting H, Maat DZ (1987) Characterization and identification of potato virus and viroids. Viruses of potatoes and seed-potato production. Pudoc Wageningen. pp. 23-29.

60. Watts NR, Singh M, Singh RP (1997) Potato virus X isolates from potato collected in eastern Canada with different symptoms in tobacco differ in their coat proteins. $\mathrm{Am}$ Potato J 74: 245-253.

61. Baranova GV, Kushnirenko OA, Kraev VG, Lagus LI (1997) Study the template dependence and specificity of RNA-replicase from Datura plants infected with potato virus X. Mikrobiologichnii-Zhurnalia 59: 41-47.

62. Gonzalez-Jara P, Tenllado F, Martinez GB, Atencio FA, Barajas D, et al. (2004) Host dependent differences during synergistic infection by potyvirus with Potato virus $\mathrm{X}$. Molecular Plant Pathol. 5: 29-35.

63. Howard AR, Heppler ML, Ju HL, Krishnamurthy K, Payton ME, et al. (2004) Potato virus $\mathrm{X}$ TGBp1 induces plasmodesmata gating and moves between cells in several host species whereas CP moves only in N. benthamiana leaves. Virology 328: 185-197.

64. Balogun OS, Teroako T, Kunimi T (2005) Influence of the host cultivar on disease and viral accumulation dynamics in tomato under mixed infection with potato virus $\mathrm{X}$ and tomato mosaic virus. Phytipathologia Mediterranca 44: 29-37.

65. Sapotsky MV, Romanova SA, Polyakova AM, Malinovsky VI (2005) The correlation between severity of disease symptoms and the accumulation of viral antigen and acidic pathogenesis related proteins in the leaves of thorn-apple plants infected with different isolates of potato virus X. Phytopathology 153: 440-444.

66. Kagiwada S, Yamaji Y, Komatsu K, Takahashi S, Mori T, et al. (2005) A single amino acid residue of RNA dependent RNA polymerase in the potato virus $\mathrm{X}$ genome determines the symptoms in Nicotiana plants. Virus Res 110: 177-182. 
67. Komatsu K, Kagiwada S, Takahashi S, Mori T, Yamaji Y, et al. (2005). Phylogenetic characteristics, genomic heterogencity and symptomatic variation of five closely related Japanese strains of potato virus X. Virus-Genes 31: 99-105.

68. Li XS, Cao YY, Zhou T, Cheng YQ, Li HF, et al. (2008) Orychophragmus violeceus, a new host of potato virus $\mathrm{X}$, reported from China.

69. Petrzik K (2009) Occurrence of Potato virus X on hybrid dock in Czech Republic. Acta Virol 53: 49-52. [Crossref]

70. Lapshina LA, Reunov AV, Nagorskaia VP, Zviagintseva TN, Shevchenko NM (2009) Effect of fucoidan on the ultrastructure of mesophyll cells of Datura stramonium L. and accumulation of potato virus $\mathrm{X}$ in them]. Tsitologiia 51: 484-489. [Crossref]

71. Mosahebi G, Koohi-Habibi M, Okhovvat SM (2005) Study on potato virus M (PVM) occurrence in potato fields in Iran. Commun Agric Appl Biol Sci 70: 441-443. [Crossref]

72. Awasthi LP, Singh S (2006) Management of Papaya ringspot virus in nursery by phytochemicals. XVI Annual convention and International Symposium on Management of Vector Borne Viruses. Indian Virological Society and ICRISAT, Hyderabad, Andhra Pradesh.

73. Wright NS, Mellor FC, Cole EF, Hyams CM (1977) Control of PVX and PVS in seed potatoes. Can Agric 22: 14-16.

74. Darda G (1998) A new test combination: DAS-ELISA with subsequent amplified ELISA on the same microtitre plate for detection of potato virus $\mathrm{X}$ in potato tubers. Zeitschrift-fur-Pflanzenkrankheiten -und-Pflanzenschutz 105: 105-113.

75. Ghaffer AMH, Sadik AS, Hari H (1999) Effect of temperature on multiplication of potato virus $\mathrm{X}$ and tobacco etch potyvirus in tobacco plants. J Agric Sci 7: 1-15.

76. Soliman AM, Shalaby AA, Barsoum BN, Nakhla GG, Mazyad MK, et al. (2000) Molecular characterization and RT-PCR-ELISA detection of a potato virus X (PVX) isolate from Egypt. 4: 1791-1804.

77. Chaubey AN, Awasthi LP, Singh SP (2014a) Impact of climate on the development of viral diseases in potato. Research \& Review: Journal of Agriculture Science and Technology 3: 17-19.

78. Slack SA (2001) Disease caused by viruses and viroids. In: Compendium of potato diseases (2nd Edn) Stevenson WR, Loria R, France GD, Weingartner DP (Eds). Am Phytopathol Soc pp. 57-72.

79. Balagun OS, Xu L, Teraoka T, Hosokawa D (2002) Effect of single and double infections with potato virus $\mathrm{X}$ and tobacco mosaic virus on disease development, plant growth and virus accumulation in tomato. Fitopatologia-Brasileira 27: 241-248.

80. Zhang Z, Wei C, Ding M, Fang Q, Peng L, et al. (2003) Purification and identification of potato virus $\mathrm{X}$ isolated from potato cv. Zhongdianhong. China J Agric Res 16: 78-81.

81. Qu J, Zhu C, Wen F, Guo X, Song Y (2003) Coat protein gene analysis and identification of an isolate of potato virus X. Acta Phytophylacica-Sinica 30: 358-364.

82. Wu Z, Zhou X (2005) Production and application of monoclonal antibodies against potato virus X. J Zhejiang 31: 608-612.

83. Cerovska N, Hoffmeisterova H, Moravec T, Plchova H, Folwarczena J, et al. (2008) Optimum storage conditions for product of transiently expressed epitopes of Human papillomavirus using potato virus X based vector. Biologia-Plantarum 52: 184-186.

84. Beemster ABR, De Bokx JA (1987) Virus, viroids, mycoplasms and diseases with a virus-like aetiology. In: viruses of potatoes and seed-potato production. de Bokx JA, Want V (Eds) Podoc Wageningen. pp. 84-113.

85. Koening R, Lesemann DE (1978) Potexvirus group. CMI/AAB Description of plant viruses No. 200: 5 .

86. Atabekov J, Dobrov E, Karpova O, Rodionova N (2007) Potato virus X: structure, disassembly and reconstitution. Mol Plant Pathol 8: 667-675. [Crossref]

87. Agur M (1998) Analysis of resistance in potato varieties to infection by potato virus $\mathrm{M}$ isolates, PVMEre.

88. Khan MA, Naveed Q (2002) Screening of potato germplasm against potato virus X and Y based on infectivity assays. Pakistan J Phytopathol 14: 154-158.

89. Khan MA, Waqas A, Khan SM (2002) Varietal screening against potato leaf roll virus based on biological assays. Pakistan J Phytopath 14: 151-153.

90. Naveed Q, Khan MA, Rashid A (2003) Correlation of environmental conditions with PVX and PVY disease severities recorded on 21 advance lines/varieties of potato. International J Agric Bio 5: 181-184.

91. Awasthi LP, Kumar P (2003a) Prevention of infection and multiplication of Cucumber green mottle mosaic virus in muskmelon treated with Boerhaavia diffusa. Indian Phytopath 56: 362.
92. Awasthi LP, Kumar P (2003b) Protection of cucurbitaceous crops against natural infection of virus through Boerhaavia diffusa. Indian Phytopath 56: 317.

93. Singh S, Awasthi LP (2004) Prevention of infection and spread of Mungbean yellow mosaic virus (MYMV) on urdbean (Vigna mungo) through Boerhaavia diffusa root extract. Indian J Pl Pathol 22: 50-55.

94. Lambert SJ, Hay FS, Pethybridge SJ, Wilson CR (2007) Spatiotemporal spread of potato virus $\mathrm{S}$ and potato virus $\mathrm{X}$ in seed potato in Tasmania, Australia. Plant Health Progress pp.1-5.

95. Muhammad B, Khan MA, Irfanullah M, Jamil MR, Ishfaq M (2007). Incidence of potato virus $\mathrm{X}$, potato virus $\mathrm{Y}$ and potato virus on potato cultivars in potato growing areas. J Agric Soc Sci 3: 37-38.

96. Chaubey AN, Awasthi LP, Singh SP, Abhishek (2013b) Effect of different climatic conditions on the development of potato viral diseases. Asia Pacific Congress of Virology (Virocon-2013). Amity University Uttar Pradesh, Noida, India.

97. Chaubey AN, Awasthi LP, Singh SP (2014b) Eco-friendly management Eco-friendly management of viral diseases of potato. International Research Journal of Life Sciences 2: 8-12.

98. Hooker WJ (1981) Compendium of potato diseases. The American Phytopathological Society, St. Paul, Minnesota pp. 125.

99. Kowalska A, Was M (1976) Detection of potato virus M and potato virus on test plants Potato Res 19: 131-139.

100. Kennedy JS, Day MF, Eastop VF (1962) A conspectus of aphids as vectors of plan viruses. Common wealth Institute of Entomology, London pp. 114.

101. Gibson RW (1974) The induction of top-roll symptoms on potato plants by the aphid Macrosiphum euphorbiae. Ann Appl Biol 76: 19-26.

102. Gibson RW (1975) Potato seed tubers do not transmit top-roll. Pl Pathol 24: 107-108.

103. Folson D, Simpson GW, Bonde R (1955) Maine potato diseases, insects and injuries Maine Agric Exp Stn Bull p. 469.

104. Simpson GW (1977) Potato insects and their control. In: "Potato: Production, storing Processing (2nd edn) Smith O (Ed) Avi Publ, Westport, Conecticut. pp. 550-605.

105. Van Hoff HA (1980) Aphid vectors of potato virus YN. Netherlands J Pl Pathol 86 159-162.

106. Sigvald R (1984) The relative efficiency of some aphid species as vectors of potato virus Y0 (PVY0). Potato Res 27: 285-290.

107. Bhagabati KN, Mamita S, Deka NC (1996) Incidence of potato leaf roll virus (PLRV) disease in relation to aphid vector population under potato based intercropping system. J Agric Sci 9: 192-194.

108. Roosen J, Huffaker RG, Felwell RJ, Marsh TL, Mittelhammer RC (1997) The relation to potato leaf roll virus net necrosis in potato tubers to the interval between planting and inoculation. Crop Prot 16: 533-539.

109. Teulon D.A.J. and Stufkens, M.A.W. (2001). Lack of relationship between aphid virus vector activity and potato leaf roll virus incidence. New-Zealand Pl Prot 54: 229-234.

110. Krishana M, Yogita V, Chakrabarti SK, Singh MN, Khurana SMP (2003) Cloning and sequencing of coat protein gene of an Indian potato leaf roll virus (PLRV) isolate and its similarity with other members of luteoviridae. Virus Genes 26: 247-253.

111. Garg ID, Khurana SMP (2003) Management of virus diseases. In: The PotatoProduction and Utilization in sub-tropics (Eds) Paul Khurana SM, Minhas JS, Pandey SK, Mehta Publication, A-16 (East), Naraina, New Delhi pp. 246-251.

112. Garg ID, Shiv K, Khurana SMP (2003) Immuno electron microscopic diagnosis of potato virus M. J Indian Potato Asso 30: 241-245.

113. Kotzampigikis A, Haristova D, Tasheva TE (2008) Distribution of potato leaf roll virus (PLRV) and potato virus Y (PVYn) in a field experiment. Bulgarian J Agric Sci 14: 56-67.

114. Zhang J, Hao W, Yu J, Jhang H, Li T, et al. (2008) Transgenic potato transformed with divalent ribozyme gene for resistance to potato leaf roll virus (PLRV). Phytopathologica sinica 38: 501-508.

115. Davis JA, Radcliffe EB (2008) The importance of an invasive aphid species in vectoring a persistently transmitted potato virus: Aphis glycines is a vector of potato leaf roll virus. Pl Dis 92: 1515-1523.

116. Natti JJ, Kirkpatrick HC, Ross AF (1953) Host range of potato leafroll virus. Am Potato J 30: 55-64. 
117. Gugerli P (1979) Potato virus A and potato leafroll virus: purification, antiserum production and serological detection in potato and test plants by enzyme-linked immunosorbent assay (ELISA). Phytopathologische Zeitschrift 96: 97-107.

118. Takanami Y, Kubo S (1979) Enzyme associated purification of two phloem limited plant viruses: tobacco necrotic dwarf and potato leaf roll virus. J Gen Virol 44: 153159.

119. Chiko AW, Guthrie (1969) An hypothesis for selection of strains of potato leafroll virus by passage through Physalis froridana. American Potato J 46: 155-167.

120. Savenkov EL, Valkonen JPT (2001) Potyviral helper component proteinase expressed in transgenic plants enhances titres of potato leaf roll virus but does not alleviate its phloem limitation. Virology 283: 285-293.

121. Maat DZ, Bokx JA de (1978) Potato leafroll virus: antiserum preparation and detection in potato leaves and sprouts with the enzyme-linked immunosorbent assay (ELISA). Netherlands J Pl Pathol 84: 149-156.

122. Clarke RG (1981) Potato leafroll virus purification and antiserum preparation for enzyme linked immunosorbent assays. An Potato J 58: 291-298.

123. Ambrosova SM, Malofeeva YS, Varitsev YA(1996) Immunochemical characterization of monoclonal antibodies to potato leaf roll virus. Bio-organicheskaya-Khimiya 22 : 24-28.

124. Seo H, Hahm Y, Oh S, Shin KY, Choi JK (1998) Diagnosis of potato leaf roll virus with digoxigenin-labelled cRNA probes. J Pl Pathol 14: 636-641.

125. Thomas PE, Hassan S, Kaniewski WK, Lawson EC, Zalewski JC (1998) A search for evidence of virus/transgene interactions in potatoes transferred with potato leaf roll virus replicase and coat genes. Molecular Breeding 4: 407-417.

126. Souza-Dias JCA, Russo P, Miller L, Slack SA (1999) Comparison of nucleotide sequences from three potato leaf roll virus (PLRV) isolates collected in Brazil. Am J Potato Res 76: 17-24.

127. Akanda MAM, Islam S, Kandu AK (2002) Serological detection of potato leaf roll virus and potato virus $\mathrm{Y}$ from foundation seed of potato. Bangladesh J Pl Pathol 18: $97-100$

128. Xingquan W, Tan X, Chen S, Xie L (2006) Cloning and sequence analysis of CP gene of a potato leaf roll virus isolate from Fujian. J Henan Agric Univ 4: 391-393.

129. Guo Z, Sun Y, Zhang X, Zhang J, Bai Y (2007) Cloning and sequencing of IS gene of Inner Monogolian isolate of PLRV (Potato leaf roll virus). Acta Agricultural Boreali Sinica 22: 19-23.

130. Rowhani A, Stace-Smith R (1979) Purification and characterization of potato leafroll virus. Virology 98: 45-54. [Crossref]

131. Rochow WF, Duffus JE (1981) Luteovirus and yellow diseases. In: Hand book of plant virus infections Kurstak E (Ed) Holland, London. pp. 147-170.

132. Hassan A, Jan H, Muhaddad A (1997) Sources of potato seed in relation to production and potato leaf roll virus in Pakhal plain and Kaghun. Valley of Hazara division. Pakistan J Phytopathol 9: 148-151.

133. Schuta LR, Lima NVC (1997) Effect of potato leaf roll virus (PLRV) on the content of macronutrients in potato plants (Solanum tuberosum L. var. Bintje) grown under different levels of potassium fertilization. Revista-do-sector-de-Ciencias-Agrarias 16: 77-82.

134. Petr P (1998) Evaluation of resistance to potato leaf roll virus (PVRV) in selected potato clones. J Gen Bree 34: 21-26.

135. Yldrm MD, Calskan C, Budak N, Caylak O (1998) Screening potato clones for potato leaf roll virus (PLRV) resistance and high yielding capacity in the western Turkey. Turkish J Field Crops 3: 40-46.

136. Sher H, Asad A, Akhatar A (2000) Occurrence and distribution of potato leaf virus and potato virus $\mathrm{Y}$ in major potato growing areas of North-West Frontier Province. Pakistan J Phytopath 12: 145-151.

137. Bostan H, Guclu C, Ozturk E, Ozdemir I, Ilbagi H (2006). Influence of aphids on the epidemiology of potato virus diseases (PVY, PVS and PLRV) in the high-altitude areas of Turkey. Pakistan J Bio Sci 9: 759-765.

138. Chatzivasriliou EK, Moschos E, Gazi S, Koutretsis P, Tsoukai M (2008) Infection of potato crops and seeds with potato virus $\mathrm{Y}$ and potato leaf roll virus in Greece. $J P l$ Pathol 90: 253-261.

139. Ali MC, Maoka T, Natsuaki KT (2008) The occurrence of potato viruses in Syria and the molecular detection and characterization of Syria potato virus $\mathrm{S}$ isolates. Potato Res 51: 151-161.
140. Liu B, Xie Z, Peng H, Xi Y, Gao B (2008) The relation to field resistance and yield during different virus free potato varieties. J Agril Sci 21: 1002-1005.

141. German TL (2001) Disease caused by viruses and viroids. In: Compendium of Potato diseases (2nd Edn) Stevenson WR, Loria R, France GD, Weingartner DP (Eds). Am Phytopathol Soc pp. 57-72.

142. Bagnall RH, Larson RH, Walker JC (1956) Isolation of the IVM factor (Potato virus M) from Datura metel. Potato virus $\mathrm{M}, \mathrm{S}$ and $\mathrm{X}$ in relation to interveinal mosaic of the Irish Cobbler variety. American Potato J p. 33.

143. Lee ST (1972) Occuence of potato virus M and its strains in Taiwan. Proc Natl Sci Counc Repub J 5: 9-108.

144. Chrazanowska M, Zagorska H (1996) Reaction of polish potato cultivars to the severe strain of PVM after mechanical inoculation. Biuletyn Instytutu Ziemniaka 46: 17-27.

145. Salamon $P$ (2006) Viral diseases and viruses of cultivated and wild solanaceae plants in Hungary. 6. Woody nightshade (Solanum dulcamara L.) as a natural host of a new strain of potato virus M (PVM). Novenyvedelem 42 (3): 121-134.

146. Salaman RN, Lepelly RH (1930) Paracrinkle: a potato disease of the virus group Proc. Roy London Bulletin 106: 140-175.

147. Wetter C, Volk J (1960) Versuche zur Ubertraguang der kartoffeiviren M and S durch Myzus persicae Sulz. [Experiments onthe transmission of potato virus $\mathrm{M}$ and $\mathrm{S}$ by $\mathrm{M}$. persicae]. Eur Potato J 3: 158-163.

148. Taylor LR (1981) Aphid forecastig and pathogens. A handbook for aphid identification, Rothamsted Experimental Station. Harpenden pp. 171.

149. Marczewski W, Strzelczyk ZD, Henning J, Witek K, Gebhardt C (2006) Potato chromosomes IX and XI carry genes for resistance to potato virus M. Theoretical and Applied Genetics 112: 1232-1238.

150. Schultz ES (1951) Interveinal mosaic of potato (Abs.). Phytopathology 41: 564.

151. Schultz ES (1956) Personal communications.

152. Bagnall RH, Wetter C, Larson RH (1959) Differential host and serological relationship of potato virus M, potato virus S and carnation latent virus. Phytopathol 49: 435-442.

153. Brandes J, Wetter C, Bagnall RH, Larson RH (1959) Size and shape of the particles of potato virus S, potato virus M and carnation latent virus. Phytopathol 49: 443-446.

154. Tu JC, Hiruki C (1970) Ultrastructure of potato infected with potato virus M. Virology 42: 238-242. [Crossref]

155. Thornberry HH (1966) Index of plant virus diseases. US Dep Agric Handbook pp. 307.

156. Ross H (1968) Lycopersicum chilense Dun., eine testpflanze fur die beiden Karoteffelviren $\mathrm{M}$ and $\mathrm{S}$. [Lycopersicon chilense) a test plant for the two potato viruses M and S. Eur Potato J 11: 281-286.

157. Grieco F, Franco A, Gallitelli D (1997) Potato virus M in tomato crops in southern Italy. $J$ Pl Pathol 78: 45-49.

158. Jeffries CJ (1998) Potato. FAO/IPGR Technical guidelines for the safe movement of germplasm pp. 177.

159. Verhoeven JTJ, Jansen CCC, Roenhorst JW (2006) First report of potato virus M and chrysanthemum stunt viroid in Solanum jasminoides. Pl Dis 90: 1359.

160. Mosahebi G, Ahoon MA, Sharifi TA, Mohammadi M, Okhovvat SM (2005) Occurrence and physico-serological properties of potato virus S (PVS) in Iran Communications in Agricultural and Applied Biological Sciences 70: 423-425.

161. Wetter C (1972) Potato virus M No 87. In: Description of plant viruses. Commonw Mycol Inst Assoc Appl Biol Kew, Survey England.

162. Kassanis B (1960) Potato virus M and Paracrinkle. Nature pp. 188-688.

63. De Bokx, Piron JD, PGM, Cother E (1980) Enzyme-linked immunosorbent assay (ELISA) for the detection of potato virus $\mathrm{S}$ and $\mathrm{M}$ in potato tubers. Netherlands $\mathrm{JPl}$ Pathol 86: 285-290.

164. Faccicoli G, Colombarini A (1996) Correlation of potato virus S and virus M contents of potato meristem tips with the percentage of virus free plantlets produced in vitro. Potato Res 39: 129-140.

165. Flatken S, Ungewickell V, Menzel W, Maiss E (2008) Construction of an infectious full-length cDNA clone of potato virus M. Arch Virol 153: 1385-1389. [Crossref]

166. Shiv K, Chaubey IP, Sarjeet S (2001) Prevalence of potato virus M in potato seed stoks in Indogangetic plains. J Indian Potato Asso 28: 111-112. 
167. Abou J, Hana S, Abib S (2001) Incidence of potato virus disease and their significance for a seed certification programme in Lebanon. Phytopathologia 40: 113-118.

168. Brunt AA (2001) Potato virus M (MVM; Genus Carlavirus). Virus and virus like diseases of potatoes and production of seed potatoes. Horticulture Research International Wellesbourne, Warwicks, UK pp. 109-112.

169. Zagorask H, Chrzanowska M (2007) Analysis of the results of studies conducted in 1973-2005 on reaction of potato cultivars to potato virus M. Biuletyn Instytutu Hodowli-i-Aklimatyzacji Roslin 243: 227-234.

170. Lang Q, Chen J, Tianzhen F, Zhiyou D (2007) Occurrence and molecular detection of potato virus S (PVS) in Zhejiang province. Acta Phytopathologica-Sincia 37: 217 220

171. Janczur KL, Nakhla MK, Charkowski AO (2006) Multiplex detection of potato virus $\mathrm{S}$, potato virus $\mathrm{X}$ and potato virus $\mathrm{Y}$ by non-radioactive nucleic acid spot hybridization in potato tissue culture plantlets. J Potato Res 83: 495-501.

172. Bagnall RH (1981) Disease in the presence of infectious pathogen. In: Compendium of Potato Diseases. Hooker WJ (Ed). Am Phytopathol Soc pp. 27-90.

173. Bagnall RH and Larson RH (1957) Potato virus S. Phytopathol 47: 2-3.

174. Outoter FC (1952) A new potato virus. Proc Cot Potato Virus Diseases, WageningenLisse pp. 83-84.

175. Dykstra TP (1939) Comparative studies of some European and American potato viruses. Phytopathology 26: 597-606.

176. BAWDEN FC, KASSANIS B, NIXON HL (1950) The mechanical transmission and some properties of potato paracrinkle virus. J Gen Microbiol 4: 210-219. [Crossref]

177. Matousek J, Schubert J, PtÃcek J, KozlovÃ P, DÄdic P (2005) Complete nucleotide sequence and molecular probing of potato virus S genome. Acta Virol 49: 195-205. [Crossref]

178. Wetter C, Brandes J (1955) Elektronenmikroskopische. Untersuchungen. Uber Gestalt und Grosse des Kartoffel-S-virus. Naturwissenschaften 42: 100-101.

179. De Bokx JA (1969) Particle lenght of various isolates of potato virus S. Neth J Pl Pathol 75: 144-146.

180. Kowalska A (1977) Reaction of red kidney bean to potato virus S. Potato Res 20: 85-88.

181. Ksiazek D (1975) Studies on the reaction of some weeds to potato virus M.S. and Y. Pl Pathol p. 55-842.

182. KohlerE (1953) Ein unbekanntes kartoffelvirus. Nachrichlbl. Dtsch. Pflanzenuschutzd 7: $22-23$.

183. Joung Y, Jeon J, Choi K, Kim H, Oh H, et al. (1997) Detection of potato virus S using ELISA and RT-PCR technique. Korian J Pl Pathol 13: 317-322.

184. Ptacek J, Matousek J, Dedic P (1999) Diagnosis of potato virus S (PVS) by techniques of polymerase chain reaction (RT-PCR) and by molecular hybridization (cDNA probes). Vyzkumny Ustav Bramborarsky Havlickuv, Vedecke Prace 13: 103-111.

185. Garcia AL, Sarria HZ, Pichardo MT, Perez MB (2001) Meristem culture for the elimination of the virus $\mathrm{S}$ of the potato in plants cultivated in vitro. Biot Veg 1: 117119 .

186. Li G, Yang Y, Wang X, Yang Y, Bi Y (2004) Cloning of potato virus S coat protein gene and its expression in E. coli JM 109. Acta Horticulturae Sinica 31: 517-519.

187. Wetter C, Brandes J (1956) Untersuchungen uber das kartoffel-S Virus. Phytopathol Z 26: 81-92.

188. Dedic P, Ptacek J, Pohorela M, Domkarova J (1996) Detection of potato virus S in domestic and imported planting material. Vedecke Prace Vyzkumny a slechtitelsky ustav bramborasky-v-havlickove brode 12: 27-25

189. Urbanaviciene L (2000) Investigations of potato virus S isolates in Lithuania. Biologia 1: 12-14.

190. Xingquan W, Chen S, Wei G, Wu Z, Xie L (2005) The molecular identification and the distribution of potato virus $\mathrm{S}$ in Fujian Province. Acta Phytophylacica-Sinica 32: 133-137.

191. Baldauf PM, Gray SM, Perry KL (2006) Biological and serological properties of potato virus $\mathrm{Y}$ isolates in northeastern united states potato. Pl Dis 90: 559-566.

192. Verma HN, Awasthi LP (1979 b) Antiviral activity of Boerhaavia diftusa root extract and the physical properties of the virus inhibitor. J Bot 57: 926-932.
193. Verma HN, Awasthi LP (1979a) Prevention of virus infection and multiplication by leaf extract of Euphorbia hirta and the properties of the virus inhibitors. New Botanist 6: $44-59$.

194. Verma HN, Awasthi LP (1979c) Antiviral activity of Boerhaavia diffusa root extracts and the physical properties of the virus inhibitor. Can J Bot 57: 926-932.

195. Verma HN, Awasthi LP, Saxena KC (1979c) Isolation of the virus inhibitor from the root extact of Boerhaavia diffusa inducing systemic resistance in plants. Can J Bot 57: 1214-1217.

196. Verma HN, Awasthi LP, Mukerjee K (1979 a) Induction of systemic resistance by antiviral plant extracts in non-hypersensitive hosts. Zetschrift Pfanzenk Pflanzenschetz 86: 735-740.

197. Verma HN, Awasthi LP, Mukerjee K (1979b). Prevention of virus infection and multiplication by extracts from medicinal plants. Pytopath Z 96: 71-76

198. Awasthi LP, Mukerjee K (1980) Protection of Potato virus X infection by plant extracts. Biologic Plantarum 22: 205-209.

199. Verma HN, Awasthi LP, Kumar V, Chaudhary B, Rastogi P, et al. (1980) Control of plant virus diseases by extract from higher plants. J Ind Bot Soc 59: 30.

200. Verma VS, Raychaudhari SP, Khan AM (1969) Properties and Nature of inhibitor of Potato virus X in four medicinal plant extracts. Biologia Plantarum 11: 384-387.

201. Yukawa TA, Kurokawa M, Sato H, Yoshida Y, Kageyama S, et al. (1970). Effect of tannins from Terminalia chebula Retz. on the infectivity of Potato virus X. Acto Microbiol Pol B 32: 127-132.

202. Awasthi LP, Chowdhury B, Verma HN (1984) Prevention of plant virus disease by Boerhaavia diffusa inhibitor. Int $J$ Trp Plant Disease 2: 41-44.

203. Verma HN, Rastogi P, Prasad V, Srivastava S (1985) A possible control of natural virus infection of Vigna radiata and Vigna mungo by plant extracts. Indian J Plant Pthol 3: 21-24.

204. Singh SK, Awasthi LP, Singh S, Sharma NK (2011a) Protection of mungbean and urdbean crops against vector borne mungbean yellow mosaic virus through botanicals. Curr Bot 2: 08-11.

205. Singh, Shyam, Awasthi LP, Singh RK (2011b) Induction of systemic resistance through antiviral agents of plant origin, in papaya (Carica papaya L.), against papaya ring spot disease. Achieves of Phytopathology and Plant Protection 44: 1676-1682.

206. Singh, Sanjay, Awasthi LP (2012) Control of Yellow Mosaic disease of Mungbean (Vigna radiate L. Wilczek) with Chemicals and Botanicals.

207. Awasthi LP, Kempiak G, Rizivi SMA (1989) Prevention of Oat sterile dwarf virus infection and suppression of disease symptoms in Oat plants by Boerhaavia diffusa glycoprotein. Fifth convention, Indian Virological Society and National Symposium on Epidemiology of Viral Diseases, CPRI, Shimla Pp.17-19.

208. Verma A, Verma HN (1993) Management of viral disease of mungbean by Clerodendrum leaf extracts. Indian J Pl Pathol 11: 63-65.

209. Verma A, Singh RB (1994) Clerodendrum aculeatum a possible prophylactic agent against natural viral infection in mungbean. Ann Plant Prot Sci 2: 60-63.

210. Verma HN, Varsha (1995) Induction of systemic resistance by leaf extract of Clerodendrum aculealum in sunnhemp against Sunnhemp resette virus. Indian Phytopath 48: 218-221.

211. Verma HN, Srivastava S, Varsha, Kumar D (1996) Induction of systemic resistance in plants against viruses by a basic protein from Clerodendrum aculealum leaves. Phytopath 86: 485-492.

212. Awasthi LP, Rizivi SMA (1999) Effect of Boerhaavia diffusa glycoprotein on the transmission of Tomato yellow leaf curl virus by Bemisia tabaci Gen. National Symposium on Vectors of Plant Disease, N.D. University of Agriculture \& Technology, Kumarganj, Faizabad 56: 11-13.

213. Jayashree K, Pan KB, Sabitha D (1999) Effect of plant extracts and derivatives, butter milk and virus inhibitory chemicals on Pumpkin yellow vein mosaic virus transmission. Indian Phytopath 52: 357-361.

214. Surendran M, Shanmugam V, Rajagopalan B, Ramanian N (1999) Efficacy of botanicals on Brinjal mosaic virus. Plant Disease Research 14: 63-66.

215. Jimenez SFJ, Agramonte MD (1999) Evaluation of the effectiveness of chemical control against insect vectors of pawpaw (Carica papaya) diseases. CEIBA 40: 229-233.

216. Madrigal JEP, Diaz DR, Jimenez JAV, Vazquez RM, Lagunes DAR, et al. (2000) Aqueous extracts of neem seeds (Azadirachta indica) for the integrated management of papaya (Carica papaya L.). Rivista-Chapingo-Seris. Horticulture 6: 79-87. 
217. Singh S (2002) Studies on management of yellow mosaic disease of mungbean (Vigna mungo (L.) Hepper) through botanicals M.Sc. (Ag.) Thesis. N.D University of Agriculture \& Technology, Kumarganj, Faizabad (U.P.) pp 1-100.

218. Singh S, Awasthi LP (2002) Prevention of infection and spread of Bean common mosaic virus disease of mungbean and urdbean through botanicals. Indian J Plant Pathol 11: 63-65.

219. Chaubey AN, Awasthi LP, Singh SP (2013a) Viral diseases of potato and their management with antiviral substances of medicinal plants origin. National symposium on abiotic and biotic stress management in vegetable crops. Indian Institute of Vegetable Research, Varanasi.

220. Chaubey AN, Mishra RS, Awasthi LP (2017) Ecofriendly management of leaf curl disease of chilli through botanical biopesticides. Sci Fed Virology Research Journal 1: 1-7.

221. Singh S, Awasthi LP, Verma HN (2004) Prevention and control of yellow mosaic disease of mungbean by application of aqueous root extract of Boerhaavia diffusa. Indian Phytopath 57: 303-304

222. Singh S, Awasthi LP, Khan MN (2005) Management of yellow mosaic disease of mungbean and urdbean through aqueous root extract of Boerhaavia diffusa. New Botanists XXXII: 55- 62.

223. Singh AK, Ahmad Najam, Pant AB, Awasthi LP, Verma HN, et al. (2012) Modulatory effect of phytoproteins isolated from roots of Boerhaavia diffusa and leaves of Clerodendrum aculeatu on neoplastic growth of human breast cancer cell line. Journal of Agricultural Science and Technology, Open Access Scientific Reports 1: 1-9.

224. Aprahamian CJ, Morgan TL, Harmon CM, Georgeson KE, Barnhart DC (2006) U-stitch laparoscopic gastrostomy technique has a low rate of complications and allows primary button placement: experience with 461 pediatric procedures. $J$ Laparoendosc Adv Surg Tech A 16: 643-649. [Crossref]

225. Sharma NK, Awasthi LP (2017) Molecular characterization of antiviral Proteins, isolated from host Plants, pretreated with antiviral glycoprotein, isolated from roots of Boerhaavia diffusa plants. Journal of Human Virology and Retrovirology 5: 1-5.

226. Singh, Shyam, Jangre A, Kumar P, Awasthi LP (2017a) Studies on the molecular variability in Indian isolates of Papaya ring spot virus. Virology Research Journal 1: $10-16$

227. Najam A, Awasthi LP, Verma HN, Tiwari, Raghvendra (2017) Effect of bioenhancers on the antiviral resistance inducing activity of phytoproteins, isolated from roots of Boerhaavia diffusa and leaves of Clerodendrum aculeatum.

228. Awasthi LP, Singh SP, Verma HN, Kluge S (2013) Further Studies on the Antiviral Agent(s) Isolated from Host Plants, Pre-treated with Boerhaavia diffusa Glycoprotein Virology and Mycology 3: 124

229. Awasthi LP, Verma HN, Kluge S (2016) A possible mechanism of action for the Inhibition of plant viruses by an antiviral glycoprotein isolated from Boerhaavia diffusa roots. Jour Virology Antiviral Research 5: 1-8.
230. Awasthi LP, Singh Shyam, Sharma NK, Singh SK (2011) Induction of systemic resistance through antiviral agents of plant origin against papaya ring spot virus disease in papaya (Carica papaya L.). International Journal of Sustainable Agriculture 3: 54-57.

231. Awasthi LP, Singh, Samir Pratap, Tripathi D (2014b) Eco-friendly Management of the Viral Diseases of Chilli (Capsicum annum L.). Research \& Review: Journal of Agriculture Science and Technology 3: 11-16.

232. Awasthi LP, Singh, Samir Pratap (2015) Clerodendrum-A Novel Herb having Broad Spectrum Antimicrobial Properties. Asian Agri History 19: 33-44.

233. Pandey AK, Awasthi LP, Pandey VP, Sharma NK, Kumar A, et al. (2014) Bioefficacy of root extract of Boerhaavia diffusa on yellow disease of ginger. American International Journal of Research in Formal, Applied and Natural Sciences 5: 79-80.

234. Singh S, Jangre N, Kumar S, Bisaria S, Awasthi LP (2016) Effect of artificial and natural infection of papaya ring spot virus on different papaya cultivars in Uttar Pradesh. Jour Soil and Crops 26: 203-212.

235. He C, Zhang W, Hu X, Singh M, Xiong X, et al. (2014) Molecular characterization of a Chinese isolate of potato virus A (PVA) and evidence of a genome recombination event between PVA variants at the 3'-proximal end of the genome. Arch Virol 159: 2457-2462. [Crossref]

236. Sui Q, Liu C (2016) Response of nitrite accumulation and microbial community to free ammonia and dissolved oxygen treatment of high ammonium wastewater. Appl Microbiol Biotechnol 100: 4177-4187. [Crossref]

237. Wang F, Sun Y, Ruan J, Chen R, Chen X, et al. (2016) Using Small RNA Deep Sequencing Data to Detect Human Viruses. Biomed Res Int 2: 8-12. [Crossref]

238. Duarte LML, Salatino MLF, Salatino A, Negri G, Barradas MM (2008) Effect of potato virus $\mathrm{X}$ on total phenol and alkaloid contents in Datura stramonium leaves. Summa-Phytopathologia 34: 65-67.

239. http://www.ncbi.nlm.nih.gov/ICTVbd/ICTVdB/index.htm

240. Schmid D, Kuo HW, Hell M, Kasper S, Lederer I, et al. (2011) Foodborne gastroenteritis outbreak in an Austrian healthcare facility caused by asymptomatic, norovirus-excreting kitchen staff. J Hosp Infect 77: 237-241. [Crossref]

241. McMurray JJ, Krum H, Abraham WT, Dickstein K, Køber LV, et al. (2016) Aliskiren, Enalapril, or Aliskiren and Enalapril in Heart Failure. N Engl J Med 374: 1521-1532. [Crossref]

242. Vander Plank JE (1963) Plant Disease: Epidemics and control. Academic Press. New York, London pp. 349.

Copyright: (C2017 Awasthi LP. This is an open-access article distributed under the terms of the Creative Commons Attribution License, which permits unrestricted use, distribution, and reproduction in any medium, provided the original author and source are credited. 